NBER WORKING PAPER SERIES

\title{
INTERNATIONAL BORROWING AND MACROECONOMIC PERFORMANCE IN ARGENTINA
}

\author{
Kathryn M.E. Dominguez \\ Linda L. Tesar \\ Working Paper 11353 \\ http://www.nber.org/papers/w11353 \\ NATIONAL BUREAU OF ECONOMIC RESEARCH \\ 1050 Massachusetts Avenue \\ Cambridge, MA 02138 \\ May 2005
}

Prepared for the NBER conference on International Capital Flows, December 17-18, 2004 in Santa Barbara, California. Forthcoming in an NBER book to be published by the University of Chicago Press. We thank Ron Alquist for excellent research assistance. We are grateful for comments and suggestions from Nicolas Magud, Juan Carlos Hallak, Alan Taylor, Martin Feldstein, Barry Eichengreen, Charlie Calomiris, and Sebastian Edwards. The views expressed in this document are the authors' and do not necessarily reflect those of the National Bureau of Economic Research. The views expressed herein are those of the author(s) and do not necessarily reflect the views of the National Bureau of Economic Research.

(C2005 by Kathryn M.E. Dominguez and Linda L. Tesar. All rights reserved. Short sections of text, not to exceed two paragraphs, may be quoted without explicit permission provided that full credit, including (C) notice, is given to the source. 
International Borrowing and Macroeconomic Performance in Argentina

Kathryn M.E. Dominguez and Linda L. Tesar

NBER Working Paper No. 11353

May 2005

JEL No. O54, F3, F21, F42

\section{$\underline{\text { ABSTRACT }}$}

This paper provides an overview of the major economic events in Argentina from the adoption of the convertibility plan in 1991 to the collapse of the exchange rate regime in 2001 . We focus on the relationship between the credibility of the currency board and capital flows, and the inescapable link between fiscal and monetary policy. Argentina inadvertently entered into a vicious circle with financial markets - one in which it felt compelled to raise the exit costs from the currency board in order to maintain the regime's credibility. As exit costs mounted, financial markets became increasingly concerned about the dire implications of a devaluation, which in turn, compelled the government to raise exit costs further. In the late 1990s, when Argentina went into recession, it required some sort of stimulus -either a loosening of monetary policy (i.e. a devaluation) or fiscal stimulus. But either way spelled disaster. The added pressure of capital outflow, first by international investors and then the withdrawal of deposits from the Argentine banking system, eventually tipped the scales.

Kathryn M.E. Dominguez University of Michigan School of Public Policy

440 Lorch Hall

611 Tappan Street

Ann Arbor, MI 48109-1220

and NBER

kathrynd@umich.edu

Linda L. Tesar

Department of Economics

University of Michigan

Ann Arbor, MI 48109-1220

1tesar@umich.edu 


\section{Introduction}

In the early 1990s Argentina was the darling of international capital markets and viewed by many as a model of reform for emerging markets. Early in his Presidency, Carlos Menem embarked on a bold set of economic policies, including the adoption of a currency board which pegged the peso to the dollar, a sweeping privatization program for state-owned enterprises, an overhaul of the banking system, and privatization of the public pension system. The business press marveled over the rapid turnaround in the Argentine economy. Although there were some concerns about the appropriateness and sustainability of the dollar anchor and whether the fiscal reforms were more rhetoric than reality, the policies appeared to have conquered inflation and set the country on a course of steady economic growth.

By the end of the 1990s, however, Argentina's situation had dramatically changed. The country had weathered the financial crises in Mexico and Asia, and despite the volatility of capital flows, Argentina's currency board remained intact and forecasts of future growth were relatively positive. The Russian default in August 1998, however, caused international investors to pull out of all emerging markets, seemingly with little regard for country-specific economic conditions. More bad luck followed in January 1999 when Brazil, Argentina's major trading partner, devalued its currency, further weakening the competitiveness of Argentine exports. Economic growth stalled and unemployment remained high. Despite the lowering of world interest rates, which helped reduce the cost of external borrowing, the economy was teetering on the brink of default. In 2001, the economy spiraled downward and depositors scrambled to pull their savings out of the banking system. In a desperate attempt to stave off disaster, the government imposed sweeping capital controls. By 2002, Argentina was in complete political and economic collapse. The currency board was abandoned, the exchange rate devalued, and eight years of growth in GDP were lost.

Argentina's situation cannot, however, be solely attributed to a run of "bad luck." Policy decisions taken during the 1990s - and just as importantly policy indecision - made the country vulnerable to the kinds of shocks that affected all emerging markets. The inability to bring fiscal policy under control, the incomplete reforms of the banking sector, and rigidities in the economy, ultimately left the country with no good solutions. What the currency board required -- constraints on fiscal policy and complete abdication of monetary policy -- proved to be beyond the political capacity of the Argentine government.

Much has been written about what happened to Argentina, why the crisis happened when it did, and what might have been done to prevent it. Although views differ about the relative importance of the various factors leading up to the collapse, there is general consensus that peso-dollar convertibility was a two-edged sword - it effectively bought the country credibility and eradicated inflation, but at too high a price. Argentina's experience reveals two major problems with currency boards. The first is reflected in the relationship between the credibility of the currency board and capital flows. Argentina inadvertently entered into a vicious circle with financial markets - one in which it felt 
compelled to raise the exit costs from the currency board in order to maintain the regime's credibility. The Argentine government raised exit costs by issuing its own debt in dollars, and by facilitating dollarization in the private sector (for example, by adopting prudential norms in the banking system that biased deposits and loans toward dollars rather than pesos). As exit costs mounted, of course, financial markets became increasingly concerned about the dire implications of a devaluation, which in turn, compelled the government to raise exit costs further.

A second, related issue has to do with the inescapable link between fiscal and monetary policy. In retrospect, it now seems clear that the lack of coordination between the fiscal policy of the central government and the provinces played a critical role in bringing about the failure of the currency board. By 1999, the economy was in a deep recession with low growth and high unemployment that required some sort of stimulus -either a loosening of monetary policy (i.e. a devaluation) or fiscal stimulus. But either way spelled disaster. A devaluation would clearly undermine the currency board. And a rise in government debt would raise suspicions that it would eventually be monetized, further undermining the value of the peso. Ultimately, fears of a devaluation resulted in more dollarization and more of a strain on the banking sector. The added pressure of capital outflow, first by international investors and then the withdrawal of deposits from the Argentine banking system, eventually tipped the scales.

The purpose of this paper is to provide an overview of the major economic events in Argentina from the adoption of the convertibility plan in 1991 to the collapse of the exchange rate regime in 2001. Section 2 reviews the key components of the Convertibility Plan and the responses of financial markets and the macroeconomy to the economic and financial reforms embodied in the Plan. Section 3 describes the set of external shocks that buffeted the economy between 1991 and 1999. Section 4 reviews the set of policy decisions and reforms that took place over that period. Section 5 examines the collapse in 2001. An Epilogue follows and a chronology of economic and political events in Argentina from 1989 through 2004 is provided in the Appendix.

\section{The Convertibility Plan}

On July 9, 1989 Carlos Menem assumed the Argentine presidency in the first peaceful transfer of power from one democratically elected leader to another since $1928 .{ }^{1} \mathrm{He}$ assumed the office six months ahead of schedule, however, due to the social and economic crisis that engulfed the country. The Austral Plan, adopted in May 1985, had replaced the peso with a new currency, and prices, wages and utility rates had been frozen in an attempt to stabilize inflation. Figure 1 shows monthly inflation and annual real GDP, two key barometers of the health of the Argentine economy over the 19802004 period. The Austral Plan had temporarily slowed inflation but did little to spur economic growth. During the period 1981 - 1989, average real GDP growth was negative at -0.7 percent and real income in 1989 had slid to 90 percent of its 1980 level. $^{2}$ In the

\footnotetext{
${ }^{1}$ For a historical perspective see, della Paolera and Taylor (2001,2002, 2003), Romero and Brennan (2002), Randall (1978) and Taylor (1998).

${ }^{2}$ Growth in real GDP based on data from International Financial Statistics, IMF.
} 
spring of 1989, inflation spiraled out of control and the Alfonsin government violently repressed mobs of angry rioters and looters.

After 18 months in office, the Menem government, under the guidance of Domingo Cavallo as Minister of the Economy, implemented far-reaching economic reforms. The capstone of the reform package was the Convertibility Plan, which was designed to eliminate Argentina's chronic inflation and restore credibility to the Argentine peso. ${ }^{3}$ The Plan pegged the peso at a one-to-one parity with the US dollar and required that twothirds of the monetary base be backed by international reserves. The other one-third could be backed by dollar-denominated Argentine central bank securities at market prices, but holdings of those securities could not expand by more than 10 percent per year. ${ }^{4}$ The Plan effectively converted the central bank into a currency board that could issue domestic currency only in exchange for foreign currency at a fixed rate. The government encouraged dollarization by making it legal to write contracts in foreign currencies and allowing foreign currencies to be used as an alternative means of payment. By 1994, over $60 \%$ of time deposits and $50 \%$ of loans to the private sector were denominated in dollars.

Until the 1990s, trade barriers and restrictions on international investment had insulated the country from international markets. Another important component of the plan was the reduction in tariffs and other barriers to trade in goods and the flow of capital. Restrictions on the entry of foreign banks were lifted. The banks faced high reserve requirements and to minimize moral hazard, deposit insurance was eliminated. Effectively, monetary policy for Argentina was set by the U.S. Federal Reserve, and the Argentine central bank had very limited scope to operate as a lender of last resort. Implications of this new role for the central bank are discussed in more detail in Section 4.b.

The Menem government also proceeded with the privatization of state-owned firms and and the deregulation of a number of industries, particularly in the petroleum and gas, electricity, and communications sectors. According to a study by Galiani, Gertler, Schargrodsky and Sturzenegger (2001), the privatization dramatically increased the profitability, sales and efficiency of non-financial as well as financial firms. One of the negative consequences of the increase in efficiency, however, was the layoff of employees. Galiani et. al. (2001) estimate employment reductions of about 40 percent as a result of privatization. One of the positive benefits, and the likely motivator for the privatization program, was the revenue accrued by the central government. Some of the revenue from privatization was used to finance another of the Menem government's reforms: the transition from a pay-as-you-go social security system to privately-managed retirement saving accounts.

An additional benefit of the privatization program was the jumpstart it provided to financial markets. Figure 2 shows the value of mergers and acquisitions of Argentine companies over the $1990-2003$ period. In the first M\&A boom in 1992, some $\$ 8$ billion

\footnotetext{
${ }^{3}$ See Cavallo and Cottani (1997) and Cavallo (2003).

${ }^{4}$ See Pou (2000) for a detailed description of the Convertibility Plan and the Central Bank Charter.
} 
in assets changed hands, over 90 percent of which were in the electricity, gas, petroleum and telecommunications industries. The second boom occurred in 1997-1999, when a much larger fraction of Argentine assets were sold to foreign residents.

The government also took some initial steps toward addressing the fiscal imbalances between the provincial and central government. Under the system of fiscal federalism in Argentina, the bulk of revenue is raised by the central government, while the provincial governments retain a large degree of autonomy in allocating expenditures. Expenditures are covered through a complicated system of intergovernmental transfers from the central government to the various provinces. Provincial governments also retained some authority to issue bonds effectively backed by the central bank. In 1991-92, the Menem government was able to lower the transfer payments to the provinces to help cover the costs of the pension reform. ${ }^{5}$

The market response to the economic reforms was swift and dramatic. Table 1 provides summary statistics of Argentina's macroeconomic performance, government budget balance, and its balance of payments. GDP growth picked up in 1991 and continued at levels above those of the rest of Latin America through 1994. The currency board was effective in taming inflation - the mean level of inflation dropped from nearly 400 percent per annum to a little under 10 percent in 1991-94 to almost zero in 1995-98. The economic boom was fueled by increases in private consumption and investment.

The lifting of controls also had a positive effect on capital inflows and on financial markets. The US investment position in Argentine equity rose from virtually nothing in the 1980s to around $\$ 5$ billion by end 1994, roughly 14 percent of Argentine market capitalization. Figure 3 shows the volume of capital inflow by type (portfolio equity flows, long-term debt, short-term debt, FDI) into Argentina over the 1986-2002 period. The country was effectively in financial autarky prior to the Menem reforms, with the exception of sovereign borrowing. That situation changed markedly in the 1990s. Capital inflows generally increased in the 1990s, with some ups and downs in the 1994-99 period. The cost of capital reflected in the Emerging Market Bond Index spread for Argentina hovered between 400 and 600 basis points from late 1993 through mid 1994.

The Convertibility Plan was far-reaching in scope and clearly had a positive impact on the economy. However, even at the time of its implementation, critics were quick to point out that it failed to grapple with some structural problems. First, the Plan failed to consolidate the budget constraint for the central government and the provinces. Second, there were concerns that the banking reforms were not as deep as they needed to be given the lack of a national lender of last resort. Third, labor market rigidities slowed the economy's response to reforms. Fourth, the question remained whether pegging to the dollar was a feasible long-term anchor for the Argentine economy, particularly given that only a small share of Argentine trade was with the US. And finally, the Plan, almost by design, did not specify an exit strategy from the peg, if it were found to be unsustainable

\footnotetext{
${ }^{5}$ See Tommasi (2002)
} 
in the long run. These issues would resurface precisely when the Argentine economy weakened and would contribute to the currency board's eventual collapse. ${ }^{6}$

\section{External Shocks: Weathering the Storm 1994-1999}

With hindsight it is easy to see that Argentina's boom in the early 1990s, with inflation under control and GDP growth on an upward path, was in fact on precarious footing. Like many other Latin American countries, the Argentine savings rate was low, and with Argentine government deficits rising, Argentina was especially dependent on foreign capital to finance new investments. Argentina's vulnerability to shifts in external capital flows was first apparent in the aftermath of the Tequila crisis, and became especially worrisome by 1999 when Brazil devalued the Real, and foreign capital again abruptly stopped flowing. The 1990s saw a number of "star" emerging markets falter, Argentina among them. The ultimate "causes" of the economic crises that shook Mexico in 1994, East Asia in 1997, Russia in 1998 and Brazil in 1999 are still under debate, but what is clear is that each of the crises took its toll on Argentina.

\section{3. a. The Tequila Financial Crises}

The start of the so-called Tequila Crisis is typically dated December 20, 1994 when the Mexican Central Bank was forced to widen its peso bands in reaction to massive capital outflows, leading to an immediate $15 \%$ devaluation and further reserve outflows. Two days later the peso was officially allowed to float and it continued to lose value while peso interest rates sharply increased. The peso depreciations led to concern that the Mexican government would default on Tesobonos (short-term government bonds denominated in pesos but indexed to the dollar) and Mexican Banks would fail (due to the large and growing proportion of non-performing floating interest rate loans).

These fears led to a chaotic exit of foreign and domestic investors from not only from Mexico, but from most of Latin America. ${ }^{7}$ Figure 4 shows U.S. net purchases of Latin American stocks and bonds, as well as net purchases of Argentine securities. Two things stand out from the figure. First, US net purchases are highly correlated across Latin American countries. Second, U.S. net purchases, which reflect a large fraction of total flows to this region, are highly volatile and are responsive to financial crises in Latin America as well as in other regions. The Tequila crisis led to a fall in Brady bond prices and stock exchange indices in most Latin American countries. Figure 5 shows the increase in the EMBI spread, which jumped to nearly 2,000 basis points.

\footnotetext{
${ }^{6}$ See, among others, Bleaney (2004), Calvo and Reinhart (2002), Edwards (2002), Feldstein (2002), Gurtner (2004), Hausmann and Velasco (2002).

${ }^{7}$ On February 1, 1995 the IMF approved an external aid package for Mexico (which included \$20b from U.S., $\$ 18 \mathrm{~b}$ from IMF, $\$ 10 \mathrm{~b}$ from BIS and $\$ 2 \mathrm{~b}$ from commercial banks) which restored investor confidence in the Mexican government's ability to honor the Tesobono contracts. Mexico announced a stringent austerity package in early March, and by July re-entered international capital markets and sold $\$ 1 \mathrm{~b}$ in twoyear dollar-denominated notes at $11 \%$, an interest rate well below the $20 \%$ plus rates on Tesobonos sold in January 1995.
} 
Argentina and Brazil were particularly hard hit by the exit of international investors from Latin America. The Argentine Merval fell 33\% between December 1, 1994 and January 10, 1995 and Argentine banks experienced significant peso deposit withdrawals and substitutions from peso to dollar accounts. ${ }^{8}$ Total (peso and dollar) deposits had increased dramatically in Argentina between March 1991 and November 1994 as Argentines became more confident about the viability of the new economic regime. At the end of 1994 the value of peso deposits in Argentina was just 9\% lower than the value of dollar deposits. During the Tequila crisis total deposits in the Argentine banking system fell for the first time since the establishment of the Convertibility Plan, with the decline falling disproportionately on peso deposits. After the Tequila crisis, the dollarization of deposits steadily increased, so that by 2001 over $80 \%$ of time deposits were denominated in dollars. ${ }^{9}$ A further indication of the impact of the Tequila crisis on the Argentine banking system shows up in M3 (currency in pesos and deposits of pesos and dollars) growth, which fell by $4.4 \%$ in 1995 . Peso prime loan rates rose from 10.1 in 1994 to $17.8 \%$ in 1995, and spreads between the peso interest rate and dollar interest rate widened by over 50 basis points. Argentine Central Bank international reserves fell by $18 \%$ in the first six months of 1995.

The Argentine government responded to the deterioration of its financial markets by putting in place a number of banking sector reforms. ${ }^{10}$ On December 28, 1994 it reduced reserve requirements on dollar deposits in order to provide more liquidity to the banking system. In mid-January reserve requirements on peso deposits were also lowered. A special security Fund managed by Banco Nacion (the largest government bank), made up of 5 private institutions and 2 public banks and funded with reserve requirements was set up to assist institutions which suffered high deposit withdrawals. (Recall that the Argentine Central Bank could not serve as a lender of last resort under the convertibility law.) In February 1995 the Trust Fund for Provincial Development was set up to help support the Provincial banks. In March a similar Trust Fund for Bank Capitalization was established, and changes were made to the Central Bank Charter to allow it to use repos and rediscounts to help troubled banks. In the same month, Argentina entered into new loan agreements with the IMF, the World Bank, and IBD and issued new bonds (for a total of $\$ 7$ billion) to increase international reserves and to fund the trust funds. In April a deposit insurance network was put in place, which covered up to $\$ 20,000$ per person (later raised to $\$ 30,000$ ) for certain bank deposits.

In the midst of the after-shocks of the Tequila crisis, President Menem won re-election in May 1995 and the run on Argentina's banks ended. Argentina's recovery from 1995 to 1996 was remarkably swift. GDP growth rallied from negative $3.6 \%$ in 1995 to positive $5.4 \%$ in 1996, led by investment and exports. However, this new growth did little to improve the fiscal situation; the government deficit as a percent of GDP remained stable

\footnotetext{
${ }^{8}$ See De La Torre, Levy Yeyati and Schumkler (2003) for a detailed description of the reactions of Argentine depositors and the banking sector to the Tequila crisis.

${ }^{9}$ Demand deposits remained largely denominated in pesos, while approximately $40 \%$ of savings deposits were dollarized in the 1990s. The large increase in deposit dollarization occurred in time deposits, which were already $60 \%$ dollarized in 1992.

${ }^{10}$ See Dabos and Gomez-Mera (1998) for a detailed description of the post-Tequila crisis banking reforms.
} 
at $1.3 \%$ over this period and the ratio of external debt to exports stayed at just under $340 \%$ (see Table 1).

While the Tequila crisis and its implications for capital flows was clearly bad luck for Argentina, it was followed by some good luck in the form of US and Brazilian policy spillovers. The Fed shifted toward more expansionary monetary policy in early 1995, leading to a fall in US interest rates and a sharp depreciation in the US dollar, in turn improving Argentine competitiveness in world markets. At the same time Brazil, Argentina's main trading partner, experienced a rise in the value of the Real, further strengthening Argentina's relative position. These "good" external shocks allowed Argentina to recover much more quickly than many had anticipated, and perhaps lulled Argentine policy makers and investors into a false sense of security. Mussa (2002) goes so far as to suggest that "were it not for the substantial improvements in bank soundness and for the external good luck, the Convertibility Plan might not have survived the Tequila crisis" (pp. 21).

\section{3.b The Asia Crisis}

There is little evidence of spillover from the Asian Crisis to Latin America until October 1997 after the attack on the Hong Kong dollar. International bond issues from Latin America declined to less than $\$ 4 \mathrm{~b}$ in the $4^{\text {th }}$ quarter of 1997 compared to $\$ 20 \mathrm{~b}$ during the previous quarter. Figure 4 shows that US net purchases of stocks and bonds in Latin America plummeted from a peak of $\$ 8$ billion in the summer of 1997 to zero in the fourth quarter. US net purchases in Argentina, however, remained positive. Stock indices fell throughout the emerging markets, with Brazil being the hardest hit, apparently because of its large current account deficit and overvalued currency. At the same time, Argentina was considered "doubly vulnerable" because of its fixed exchange rate and its dependence on Brazil as a trading partner. Portfolio equity flows to Argentine fell $380 \%$ and FDI flows fell by 23\% between 1997 and 1998, though the net flow of long term debt increased by $47 \%$. Overall, net capital flows to Argentina over this period actually rose by $5 \%$, because the sharp decline in portfolio and FDI investment were outweighed by the increase in long term debt, which accounted for a larger share of the total. The Argentine governments' only policy reaction to the Asia Crisis was the introduction of the "anti-bubble" rule, which increased the capital requirement for new mortgage loans when a nationwide real estate price index surpassed certain thresholds.

\section{3.c The Russian Default}

Just as emerging markets were beginning to recover from the Asia crisis, news that Russia would default on its sovereign bonds in August 1998 sent markets once again reeling. Few investors imagined that Russia would not be bailed out, and investors quickly realized that if Russia was to default, other vulnerable emerging markets were likely to follow. The news from Russia was a disaster for stock market investors in Argentina, as the Merval plummeted 40\% between August and September 1998. Private capital inflows to Argentina, which had already slowed in the aftermath of the Asia Crisis, now turned negative in the fourth quarter of 1998. From July to August 1998, the 
spread on Argentine sovereign bonds almost tripled. Throughout the fall, the spread remained about 400 basis points higher than the spread that prevailed in July 1998 and this, in turn, led domestic peso and dollar interest rates to rise sharply.

Calvo, Izquierdo and Talvi (2003) suggest that the dramatic stop in international capital flows to emerging markets that followed Russia's partial foreign debt repudiation provides strong evidence in favor of contagion-based (and against traditional fiscalbased) explanations for financial flows. Countries, such as Argentina and Brazil, which had little or no financial or trading ties to Russia found that their access to external capital had suddenly been cut off.

\section{3.d Brazilian Devaluation}

While Argentina was badly affected by the general exit of investors from emerging markets, Brazil - already hard hit by the Asia Crisis - was dealt a knock-out blow. ${ }^{11}$ On January 13, 1999 Gustavo Franco, the governor of the Brazilian Central Bank, resigned; and the government announced a widening of the band for the Real. This was tantamount to a devaluation of the real of $8 \%$. The financial reaction in Argentina to the Brazilian devaluation was immediate. Argentine interest rates rose sharply, the Merval plummeted, and Argentina was effectively shut out of global financial markets.

Many observers, at least with hindsight, date the beginning of the Argentine economic crisis in 2001 to the Brazilian devaluation (which, in turn, may have been set off by the Russia default). Brazil was Argentina's major trading partner, and the combination of Brazil's economic woes, which would surely reduce its import demand from Argentina, and the exit of international capital flows from the region, had serious implications for Argentina.

Returning to Figure 3, we see that that short term lending and portfolio equity flows to Argentina, whose trend had generally been rising throughout the 1990s, with short-term reversals after the Mexican and Asia crisis, sharply plummeted in 1999. Total capital flows into Argentina remained positive, primarily because of an unprecedented inflow of FDI. Interestingly, 64 percent of the inflow of FDI in that year is due to the acquisition of a single company, YPF, by Repsol, a Spanish company (see Figure 6). Netting out the YPF transaction, capital inflows would have remained positive in 1999 , but drop to $\$ 5$ billion from $\$ 20$ billion.

In a series of papers Guillermo Calvo and various co-authors ${ }^{12}$ make the case that severe capital flow reversals, such as that experienced by Argentina in 1999-2000, can be

\footnotetext{
${ }^{11}$ While portfolio flows to all emerging market countries fell dramatically after the Russia default, FDI flows were less uniform. Noteworthy in this regard is the fact that FDI flows to Brazil rose substantially in dollar terms from mid-1998 to mid-2001. Calvo, Izquierdo and Talvi (2003) suggest that it was in part these FDI flows that allowed Brazil to recover so quickly from the Russia-crisis induced Sudden Stop. Other factors in Brazil's favor were the fact that its' public debt was only partially dollarized, and that substantial fiscal retrenchment was politically feasible.

${ }^{12}$ See, for example, Calvo (1998), Calvo, Izquierdo and Talvi (2003), and Calvo, Izquierdo and Mejia (2004).
} 
triggers of subsequent economic crisis. Further, Calvo suggests that three factors in particular exacerbate an economy's vulnerability to "Sudden Stops""13: the pre-"stop" level of indebtedness, the degree of domestic liability dollarization, and the dependence on financing from abroad to pay for imports. Calvo, Izquierdo and Talvi (2003) argue that the Argentine economy in the 1990s had just the characteristics that would lead it to be hard hit in the advent of a sudden stop. Calvo, Izquierdo and Mejia (2004) date Argentina's "Sudden Stop” as starting in May 1999.

The "Sudden Stop" literature suggests that it is the capital flows (or lack thereof) themselves that are pivotal. In theory, a sudden stop in capital flows could arise from external factors, such as contagion or margin calls ${ }^{14}$ that arise from economic crises that are unrelated to the country in question. Internal factors can either mitigate or magnify the effects of the sudden stop on the economy. In countries like Argentina, with a small share of tradable goods output relative to domestic absorption of tradeable goods, a sudden stop in capital flows requires a sharp increase in the equilibrium real exchange rate to transform the current account deficit into a surplus. ${ }^{15}$ If the country also has large financial currency-denomination mismatches (for example, liability dollarization), ${ }^{16}$ the real depreciation will, in turn, lead to a weakening of corporate, and in the case of Argentina, government balance sheets. ${ }^{17}$

Argentina's experience immediately following the Russian default closely follows the Sudden Stop logic. With the fall off in capital inflows, investors and (perhaps most importantly) official creditors realized that the sustainability of Argentina's fiscal situation, though still not dramatically different from where it had been a year previous, was precarious. Calvo, Izquierdo and Talvi (2003) estimate that "once all the elements triggered by the sudden stop are factored in (valuation effects, interest rate increases, growth slowdown, and emergence of contingent liabilities from the private sector), the

\footnotetext{
${ }^{13}$ Calvo, Izquierdo and Mejia (2004) define a Sudden Stop as a sharp decline in capital flows that meets the following three criteria: (1) it contains at least one observation where the year-on-year fall in capital flows lies at least two standard deviations below its sample mean, (2) it ends once the annual change in capital flows exceeds one standard deviation below its sample mean, (3) the start is determined by the first time the annual change in capital flows falls one standard deviation below the mean.

${ }^{14}$ For a further discussion of the potential role of margin calls in sudden stops see Mendoza and Smith (2002).

${ }^{15}$ Calvo, Izquierdo and Talvi (2003) calculate that Argentina would have needed to depreciate its equilibrium real exchange rate by a whopping $46 \%$ in 1998 in order to bring down its current account to zero.

${ }^{16}$ Calvo, Izquierdo and Talvi (2003) estimate that Argentina had an extremely high degree of public sector debt mismatch in 1998. Their calculation for Argentina was 0.01 on a 1-to-0 scale with 1 representing a perfect match, and zero representing the highest degree of mismatch. Given this level of currency mismatch, the authors indicate that had there been a real depreciation of $46 \%$ (the amount needed to balance the current account), Argentina would have had a debt/GDP ratio of just under 50\% assuming no increase in interest rates and no fall in growth rates. If the contingent liabilities of the public sector that arose out of the (also highly dollarized) corporate and banking sectors are included - the debt/GDP ratio rises to well over $50 \%$.

${ }^{17}$ Government policy can, in principle, offset the negative effects of a sudden stop induced real appreciation on corporate balance sheets by providing the private sector with additional collateral. Korea, with the help of the IMF, was able to mitigate the effects of the Asian crisis induced sudden stop in this manner.
} 
primary fiscal balance needed to regain sustainability would have exceeded 3\% of GDP" in 1998 (page 32). The political economy implications of this for the Menem government, which was in its final year (presidental elections were set for December 1999 and the Argentine constitution did not allow Menem to run for a third term) were dire.

\section{3.e Reduction in world interest rates}

Argentina was on the brink of economic collapse in early 1999, but just as had been the case after the Tequila crisis, Argentina was dealt a "positive" shock in the second half of 1999 that allowed it to make another surprising, even if temporary, recovery.

In this case Argentina's rescue came from an unusual source: conditions in European financial markets. As European governments strove to meet the Mastricht criteria in the run-up to the establishment of the Euro, interest rates - which had been relatively high in a number of European countries - converged downward. This sent investors seeking higher yields to alternative markets. Argentina recognized this potential market niche and successfully floated (high yield) sovereign debt denominated in euros during this period. As Mussa (2002) points out, "the success of Argentina in floating substantial amounts of sovereign debt in global credit markets during much of 1999 and the first half of 2000 testifies both to the special conditions in those markets and to Argentine authorities' particularly deft management of public debt." (pp. 25)

\section{Internal Policy Mistakes}

At the same time that Argentina was buffeted, in both positive and negative directions, by external shocks, internal policies also had a major influence on the economy. The role of fiscal policy in the lead-up to Argentina's economic collapse is perhaps the most controversial. Mussa (2002) and the IMF $(2003,2004)$ emphasize the role of failure in fiscal policy as the root cause of the crisis. Others suggest that fiscal policy was either less central, or in some views, irrelevant. Another area of controversy is the role of the banking sector in the ultimate collapse of the economy, and in particular the currency mismatches between dollar deposits and peso-denominated assets.

\section{4. a Untamed Fiscal Policy}

Out of context, Argentina's fiscal numbers do not suggest much reason for concern. In 1993 public debt was $28 \%$ of GDP, inflation was under control and GDP growth could arguably have been expected to continue at 6-7\%. It was in this seemingly robust fiscal environment that the Argentine government decided to privatize its social security system, which produced an extra annual bill equal to $1.5 \%$ of GDP (roughly $\$ 2$ billion based on GDP in 1995), though in the long run the privatization was expected to save the government money. Other privatization efforts in the period 1993-1998 resulted in $\$ 2.9 \mathrm{~b}$ in nonrecurring revenues. By 1998 the Argentine public debt had risen to $\$ 112 \mathrm{~b}$ (as a ratio to GDP public debt had risen to 37\%), which in a broader context might still be considered moderate. 
Mussa (2002) points out, however, that this rise in public debt should have been worrisome because it occurred during a period of relatively high economic growth, it included a number of one-off revenue increases due to privatizations, and it would have looked worse but for the fact that Brady bond restructuring in 1993 involved substantial back-loading of interest payments, and "a good deal of public sector borrowing was not included in the budget" (Mussa, pp. 16). ${ }^{18}$ An assessment of the Argentine fiscal situation is further complicated by the role of provincial government spending, which is not subject to a balanced-budget rule. While provincial expenditures generally totaled less than $12 \%$ of GDP per year, the system of Argentine fiscal federalism provided little incentive for provinces to reduce spending. ${ }^{19}$

Reinhart, Rogoff and Savastano (2003) describe Argentina, which has defaulted on its debts five times since 1820, as a "serial defaulter". They show that serial defaulters can develop debt intolerance, where the risk of default begins to skyrocket at debt levels that might be quite manageable for countries with less checkered credit records. Argentina appears, in their calculations, to hit debt intolerance at debt-to-GDP ratios of only 25$30 \%$, so that alarm bells should have been ringing well before 1998 .

It is also worth remembering that Argentina's public debt during the 1990s was almost entirely denominated in foreign currencies, reflecting its limited ability to issue long-term debt in its own currency, ${ }^{20}$ itself a reflection of the fact that the convertibility regime encouraged dollar-denominated debt. ${ }^{21}$ As with other emerging market economies, Argentina could borrow only at sizable spreads over U.S. treasuries, and a negative shift in market sentiment generally resulted in higher interest rates, creating potentially explosive debt dynamics even at relatively modest levels of debt. ${ }^{22}$

At the same time that debt to GDP ratios should have sounded off alarms (and indeed, seem not to have sounded off alarms at the IMF until it was too late), Argentina's debtto-exports ratio should have also provided cause for concern. One of the costs of the currency board was a chronic over-valuation of the peso. Figure 7 shows that in the

\footnotetext{
${ }^{18}$ Perry and Servén (2002) show that if an equilibrium real exchange rate (rather than the one-for-one pesodollar rate) is used in the calculation, the public sector debt-to-GDP ratio in 2001 rises by $24 \%$.

${ }^{19}$ Expenditures in the Provinces rose steadily in the late 1990s, while transfers from the Central Government remained fixed as a constant proportion of tax revenue, which led to widening provincial deficits. See Cuevas (2003) for a discussion of reforming intergovernmental transfers.

${ }^{20}$ Eichengreen, Hausmann and Panizza (2003) describe that the difficulty of emerging market economies to issue debt in local currency can be traced to one of two (similar though distinct) phenomena: "original sin" or "debt intolerance". Original sin implies that the problem arises externally, with the structure of global portfolios and international financial markets, while debt intolerance implies that the problem arises internally, with weak institutions. In either case, the authors term "currency mismatches" as the consequence of these problems. See also Bordo et al (2003) and Rigobon (2002).

${ }^{21}$ The Argentine government did not issue peso-denominated debt, both because peso debt was more expensive (peso interest rates were always higher than dollar interest rates) and to avoid the appearance of hedging against the collapse of the Convertibility Plan.

${ }^{22}$ See, for example, Caballero and Krishnamurthy (2003), Cespedes et. Al. (2000) and Galiani et. al. (2003).
} 
period 1991-1993, the real effective peso exchange rate appreciated by almost $25 \% .^{23}$ Between 1996 and 1997 the world price of Argentina's commodity exports fell by 20\%, followed by a further decline of equal size in $1998 .^{24}$ By the end of 1998 Argentina's debt-to-export ratio was at $379 \%$ and debt service payments alone absorbed the majority of annual export earnings. In 1999, in the wake of the Brazilian devaluation, export growth fell by over 9 percent and the debt-to-export ratio rose to $427 \%$.

Finally, the Convertibility Plan did not stop the Argentine government from attempting to monetize its debts. Once foreign capital had been exhausted, the Argentine government, though unable to directly print pesos, did the next best thing by issuing smalldenomination federal bonds redeemable for federal tax payments. These bonds were called "lecop" (for letras de cancelación de obligaciones provinciales) and were considered quasi-money. Many of the provinces followed the federal government's lead and printed their own versions of quasi-money to pay for fiscal deficits. For example, the province of Buenos Aires issued "Patacón" and Córdoba issued "Lecor". In December 2001 quasi-monies issued by the federal government and the provinces exceeded $24 \%$ of pesos in circulation.

\section{4. $b$ The Role of the Banks}

The convertibility regime required an especially strong banking and financial system because restrictions on monetary policy prevented the central bank from acting as a lender of last resort through money creation. ${ }^{25}$ In the aftermath of the Tequila crisis when banks experienced massive deposit outflows, the Argentine government put in place a number of banking reforms to strengthen domestic banks, and at the same time encouraged foreign banking institutions to enter the Argentine market. ${ }^{26}$ By the end of the 1990s, Argentina was considered a model for other emerging market economies in the area of banking supervision and prudential policy. Banking system assets doubled from only 20 percent of GDP in 1991 to 40 percent of GDP in 1999.

At the same time that the Argentine government was instituting important banking sector reforms, it was also saddling its banks (and especially public banks) with public sector debt. Banking system exposure to the public sector rose from about $10 \%$ of total assets

\footnotetext{
${ }^{23}$ See Dubas, Lee and Nelson (2004).

${ }^{24}$ Another aspect of Argentina's trade patterns that increased its vulnerability, was the fact that Mercosur, established in 1991 (which created a free-trade zone among Argentina, Brazil, Paraguay, Uruguay, Chile and Bolivia) likely led to trade diversion and a less diversified trade market. Argentina went from trading around 20\% with Mercosur partners in 1991 to $45 \%$ in 1998 (with the bulk of exports going to Brazil).

${ }^{25}$ There was a proviso in the Convertibility Plan Law that allowed up to one-third of international reserves to be made up of internationally traded, dollar-denominated Argentine sovereign bonds, valued at market prices. This allowed a very limited "lender of last resort" role since the Central Bank could provide the banking system with pesos in exchange for sovereign Argentine bonds (rather than dollars).

${ }^{26}$ Foreign-owned banks presumably contribute to a strengthening of the banking system, because they are less tied to the domestic economy (and politics). In 1994 only 15\% of total Argentine banking system assets were held in foreign banks, this increased to 55\% in 1998 and 73\% in 2000 (De La Torre, Levy Yeyati and Schumkler (2003, pp.50). In the midst of the Argentine crisis, however, foreign banks reacted to the increased financial risk by reducing their exposure so that their presence did little to improve the situation.
} 
in 1995 to more than $20 \%$ by 2001 . In April 2001 alone the government placed $\$ 2 \mathrm{~b}$ of it debts with banks in Argentina, at the same time as the Central Bank charter was amended in order to allow unlimited lender-of-last-resort liquidity with the backing of government securities. ${ }^{27}$ The IMF (2003) was concerned by this growing exposure, and writes that in the 1990s the Argentine "banking system was vulnerable to three forms of shocks, all of which eventually materialized: economic downturn, devaluation of the exchange rate, and default by the public sector."

Under the currency board the Argentine banking system was heavily exposed to a devaluation of the peso against the U.S. dollar. ${ }^{28}$ While most of banks' assets and liabilities were matched in terms of their currency of denomination, many dollardenominated bank loans went to Argentine companies and households that had earnings in pesos. A large devaluation would make re-payment of those loans difficult. ${ }^{29}$

Wealthy Argentine residents have long kept bank accounts outside of Argentina in case of economic crisis. It is estimated that Argentines held over $\$ 100$ billion abroad in the 1990s, suggesting that they considered the risk of crisis (and presumably expropriation) to be substantial. Related to this is the fact that credit from the banking system to the private sector, which is generally low in Latin America, was particularly so in Argentina where bank loans to the private sector were only 23\% of GDP at its peak in 1999.

\section{The Unwinding of Reforms}

In December 1999, Fernando de la Rua was elected president and inherited a public debt in excess of $\$ 100$ billion. The new government made the decision to tighten fiscal policy with a series of tax increases, in the hope that this would further reassure investors and help to lower interest rates. But the tax increases only served to push a recovering economy back into recession. The country teetered on the edge of default throughout 2000 but once again another "good" external shock in early 2001 steadied the Argentine economy. U.S. monetary policy loosened, leading to lower U.S. interest rates and a weaker dollar. This in turn resulted in lower spreads on Argentina's bonds over US Treasuries and gave a boost to Argentina's exports.

The more aggressive fiscal policy also received the endorsement of the IMF. In March 2000 , a three-year SBA for $\$ 7.2$ billion was agreed to and, in January 2001, this was augmented by $\$ 13.7$ billion. At the same time, additional financing of $\$ 39 \mathrm{~b}$ was arranged from official and private sources. In September 2001, the IMF arrangement was further

\footnotetext{
${ }^{27}$ This amendment, ironically put in place by Domingo Cavallo, effectively dismantled the money-issuance rule under the Convertibility Plan. Cavallo had hoped that renewing the Central Banks' ability to serve as a lender-of-last-resort would encourage banks to extend credit, but it seemed to have only further weakened the credibility of the banking system.

${ }^{28}$ Although it is worth noting that prior to the Corralito dollarization in the banking system was concentrated in longer-term bank deposits and loans. Demand deposits (which were presumably used for transactions purposes) were largely denominated in pesos throughout this period.

${ }^{29}$ See De Nicolo, Honohan and Ize (2003) and Della Paolera and Taylor (2003) for further discussion of the dollarization of the banking system.
} 
augmented by $\$ 22$ billion, with up to $\$ 3$ billion to be used in support of a possible debtrestructuring operation.

However, it was too little and already too late. Argentines had begun to shift from peso to dollar deposits starting in February 2001, and this trend sharply increased during the fall, when outright withdrawals of deposits were observed throughout the banking sector. De la Torre, Levy Yeyati and Schumkler (2003) document that by November 2001, 47 of the top 50 banks had suffered major withdrawals. Between July and November 2001, Argentines withdrew over \$15 billion from banks -- on November 30, 2001 alone, banks saw withdrawals of $\$ 1.3$ billion.

On December $3^{\text {rd }}$, in a desperate effort to prevent further massive capital outflows and to halt the run on banks, the government imposed a set of draconian financial controls. The Corralito $^{30}$ limited withdrawals from bank accounts to 250 pesos per week per account ${ }^{31}$ but depositors could access their accounts to transfer funds within the banking system. Wire transfers required Central Bank approval, foreign currency futures transactions were prohibited, and in effect, all investors, foreign and domestic, were prohibited from transferring funds abroad. Depositors could exchange dollars for government bonds, but few chose to do so. The restrictions were announced as temporary measures that would remain in place until the danger of the speculative attack had passed. ${ }^{32}$ The scheduled program review by the IMF was not completed, and IMF support of Argentina was effectively withdrawn. (A detailed time line of the economic and political events that occurred during the Corralito is provided in the Appendix.)

On December $19^{\text {th }}$, the ministers in President de la Rua's cabinet resigned ${ }^{33}$ and the following day the president himself resigned. Ramon Puerta assumed the presidency in the interim as Argentine country risk skyrocketed upwards (see Figure 5 where the EMBI spread for Argentina rises from 4000 in November to just under 10,000 at the end of December 2001). A new interim president, Rodriguez Saa was named on December 23 his term would last only a week before President Eduardo Duhalde assumed power on December 30. Foreign exchange trading was suspended on December 21 and was rescheduled to resume on January 10, 2002.

In January the Argentine peso was officially devalued and all bank deposits and debts were "pesofied." Dollar deposits were converted at 1.4 pesos to the dollar, while dollar loans were subject to one-to-one conversions, effectively imposing the bulk of the costs

\footnotetext{
${ }^{30}$ A literal translation of "Corralito" is little corral. It is also the word for "playpen."

31 Perhaps unsurprisingly there was a sudden increase in the number of new bank accounts in early December. The government promptly changed the regulations so that the deposit limits applied per person rather than per account. According to the press, some 500,000 accounts were opened in the two days following the imposition of bank restrictions.

${ }^{32}$ Some of the original withdrawal limits were eventually modified, though the main restrictions on capital outflow remained in place until December 2, 2002 (exactly one year after they were first introduced). See Appendix 1 for a detailed timeline of the changes in financial market regulations in Argentina beginning in October 2001.

${ }^{33}$ Including Domingo Cavallo, who had left the office in 1996 and returned to the position of Economic Minister with the de la Rua administration.
} 
of pesofication on the banks rather than depositors. The situation of the banks was made worse by the fact that they remained exposed to foreign exchange risk on foreign liabilities, which were not pesofied. Gutierrez and Montes-Negret (2004) estimate that the banking system had a negative net worth of at least $\$ 32 b$ in January 2002. To "compensate" the banks the government issued new bonds called BODENs, which to date are illiquid (and their economic value is contingent on future debt restructuring and the governments' fiscal sustainability).

Given the political and economic chaos, the payments system ceased to function. Citizens took to the streets in protest of the economic conditions, and the foreign banks became a focus for their rage. The number of reported bankruptcies by firms and individuals reached record proportions. Growth in real GDP, consumption and investment turned sharply negative and the current account as a percent of GDP swung from -1.4 percent in 2001 to 2.9 percent in 2002 .

Amidst the economic crisis, the Corralito triggered a 50 percent expansion of the stock market. One interpretation of the stock market run up in Argentina is that for some reason investors viewed the likely devaluation of the peso as beneficial for firms, whereas in other countries such crises are generally harmful. A more plausible explanation, however, is that the idiosyncratic reaction of the Argentine stock market was largely due to the specific restrictions in the Corralito that allowed investors to use their frozen bank deposits to purchase Argentine stocks, ${ }^{34}$ and, in so doing, provided a legal mechanism for transferring funds abroad via ADRs. ${ }^{35}$

The ADR loophole worked as follows. Under the Corralito, Argentine residents were allowed to use bank deposits in excess of the $\$ 1,000$ monthly ceiling to purchase Argentine stocks. If a stock happened to be cross-listed in the U.S. those shares could be legally converted from Argentine shares into ADRs. The ADRs could then be sold in the United States and the dollar proceeds deposited in a U.S. account. ${ }^{36}$ Under normal circumstances the dollar proceeds would appear in the Argentine Balance of Payments as a capital inflow, as U.S. residents have acquired claims on Argentine firms. Under the Corralito, however, the capital inflows did not occur, and the dollars and/or shares remained outside of Argentina. In effect, the ADR "loophole" allowed Argentines to transfer monies abroad, but the transactions did not result directly in a fall in Argentina's international reserves (or a fall in Argentine bank deposits). ADR conversions, however, did reduce the number of (underlying) shares available on the local stock exchange in Buenos Aires, La Bolsa.

\footnotetext{
${ }^{34}$ See Levy-Yeyati, Schmukler and van Horen (2003) for a further discussion of the stock market boom during the Corralito.

${ }^{35}$ ADRs are American Depositary Receipts. We will use the term ADR to mean shares of Argentine firms that are also cross-listed in the U.S.

${ }^{36}$ It is clear that the Argentine government understood the role ADRs might play in allowing citizens to transfer funds abroad. However, because ADRs were associated with most of the largest publicly traded Argentine companies it would have been difficult for the government to disallow ADR transactions (and risk sending the Argentine stock market into a tail spin). Also, the fact that ADR conversions did not have a direct impact on Central Bank reserves meant that the government was less concerned about this channel of capital outflow.
} 
Auguste, Dominguez, Kamil and Tesar (2002) examine ADR premia for a number of Argentine securities. The evidence suggests that Argentine investors were willing to pay a substantial price to move their deposits out of Argentina through ADR conversions. At their peak, some ADRs were trading at a discount of in excess of 40 cents on the dollar. Figure 8 shows that a significant wedge appeared between the price of a portfolio of ADR stocks relative to non-ADR stocks beginning at the time of the Corralito. Figure 9 shows a dramatic increase in the volume of trading in ADR securities, especially for Perez Companc which seemed to be the most popular security for ADR conversions. ADR transactions alone resulted in a capital outflow of roughly $\$ 835$ million to $\$ 3.4$ billion between December 1, 2001 and May 31, 2002.

\section{Epilogue}

The Corralito, with its abrogation of individual and corporate property rights, resulted in a massive redistribution of wealth between depositors, lenders and financial institutions. Not surprisingly, the question of who owed what to whom became a matter for the courts and left the economy in a state of limbo. The courts issued a number of injunctions to savers who demanded that their dollar deposits be paid at the market exchange rate, rather than the rate decreed by the government of 1.4 pesos to the dollar, plus inflation. Honoring these injunctions cost the banks an extra 7 billion pesos. The Supreme Court finally ruled in October 2004 that the pesofication of dollar deposits that took place in 2001 was legal, relieving the banks of large potential losses from further injunctions. ${ }^{37}$ As a consequence of this recent history, most bank deposits in Argentina are short-term, which in turn limits the scope for banks to lend long-term. In early 2004, credit to the private sector amounted to only $8 \%$ of GDP.

In September 2003 Argentina again signed a three-year agreement with the IMF, which included a fiscal target of a primary surplus of 3\% of GDP in the first year (coincidently exactly the number Calvo, Izquierdo and Talvi (2003) calculated as needed in 1998 to regain sustainability). In return the IMF agreed to lend Argentina $\$ 12.5 \mathrm{~b}$, the amount that was due to the IMF over the period 2003-2006. ${ }^{38}$ In 2003, GDP grew 8.5 percent and inflation was 12.6 percent. $^{39}$

\footnotetext{
${ }^{37}$ The Supreme Court approved the conversion of fixed-term savings in dollars to pesos -- known as "pesification" -- by five to one on October 26, 2004. The president of the Court, Enrique Petracchi, abstained from voting as his savings were caught in the freeze on bank accounts when the crisis broke out.

${ }^{38}$ The IMF's lending to Argentina makes up roughly $15 \%$ of its total loans, giving Argentina quite a bit of leverage.

${ }^{39}$ See the Economist (2004) for further description of the current economic and political situation in Argentina.
} 


\section{References}

Auguste, S., Dominguez, K, Kamil, H and Tesar, L, (2002) "Cross Border Trading as a Mechanism for Capital Flight: ADRs and the Argentine Crisis," NBER working paper 9343, November.

Bekaert, G. and Harvey, C., (2003) "Chronology of Economic, Political and Financial Events in Emerging Markets: Argentina", http://www.duke.edu/ charvey/Country_risk/chronology/argentina.htm

Bleaney, M. (2004), "Argentina's Currency Board Collapse: Weak Policy or Bad Luck?", The World Economy, Vol. 27, No. 5, pp. 699-714.

Bordo, M.D., C. Meissner and A. Redish (2003), 'How “Original Sin” Was Overcome: The Evolution of External Debt Denominated In Domestic Currencies In The United States and The British Dominions 1800-2000', NBER Working Paper No 9841.

Caballero, R. and A. Krishnamurthy (2003), 'Excessive Dollar Debt: Financial Development and Underinsurance', Journal of Finance, 58(2), pp 867-893.

Calvo, G. (1998). "Capital Flows and Capital-Market Crises: The Simple Economics of Sudden Stops," Journal of Applied Economics (CEMA), 1(1): 35-54.

Calvo, G., A. Izquierdo, and L. Mejia (2004). "On The Empirics of Sudden Stops: The Relevance of Balance-Sheet Effects”, NBER Working Paper No. 10520

Calvo, G., A. Izquierdo, and E. Talvi (2003). "Sudden Stops, the Real Exchange Rate and Fiscal Sustainability: Argentina's Lessons”, NBER Working Paper No. 9828.

Calvo G. and C. Reinhart (2002), 'Fear of floating', Quarterly Journal of Economics, 17(2), pp 379-408.

Cavallo, D. and J. Cottani, (1997) "Argentina's Convertibility Plan and the IMF," American Economic Review, May, vol 87, no. 2, pp. 17-22.

Cavallo, D., (2003), "Exchange Rate Regimes," in Economic and Financial Crises in Emerging Market Economies, edited by M. Feldstein. University of Chicago Press for the NBER.

Cespedes L., R. Chang and A. Velasco (2000), 'Balance Sheets and Exchange Rate Policy', NBER Working Paper No 7840.

Cuevas, A., (2003) "Reforming Intergovernmental Fiscal Relations in Argentina," IMF Working Paper 03/90. 
Dubas, J., Lee, B., and Mark, N., (2004) Effective Exchange Rate Classifications, mimeo, October.

Dabos, M. and L. Gomez-Mera, (1998) “The Tequila Banking Crisis in Argentina," mimeo, September, University of San Andres.

della Paolera, G. and A. Taylor, eds, A New Economic History of Argentina, Cambridge: Cambridge University Press, 2003.

della Paolera, G. and A. Taylor, (2002) "Internal vs. External convertibility and emerging-market crises: Lessons from Argentine Economic History," Explorations in Economic History 39, pp. 357-389.

della Paolera, G. and A.Taylor, Straining at the Anchor: The Argentine Currency Board and the Search for Macroeconomic Stability, 1880-1935 NBER Series on Long-Term Factors in Economic Development, Chicago: University of Chicago Press, 2001.

della Paolera, G. and A.Taylor, (2003) "Gaucho Banking Redux," Economia, Spring, 142.

De La Torre, A., Levy Yeyati, E., and Schmukler, S., (2003) "Living and Dying with Hard Pegs: The Rise and Fall of Argentina's Currency Board," Economia, Spring, 43107.

De Nicolo G., P. Honohan and A. Ize (2003), 'Dollarization Of The Banking System: Good Or Bad?', IMF Working Paper No WP/03/146.

Eichengreen B., R. Hausmann and U. Panizza (2003), 'Currency Mismatches, Debt Intolerance And Original Sin: Why They Are Not The Same And Why It Matters', NBER Working Paper No 10036.

The Economist, “The long road back: A survey of Argentina,” June 52004.

Edwards S. (2002), “The Great Exchange Rate Debate After Argentina”, NBER Working Paper 9257.

Feldstein, M., (2002) Argentina's Fall: Lessons from the latest financial crisis. Foreign Affairs, March/April issue.

Galiani, S., P. Gertler, E. Schargrodsky and F. Sturzenegger, (2001) "The Benefits and Costs of Privatization in Argentina: A Microeconomic Analysis," Working paper.

Galiani, S. Levy Yeyati, E., and Schargrodsky, E., (2003) "Financial Dollarization and Debt Deflation under a Currency Board: The Case of Argentina", Emerging Market Review, December, v 4., 4. 340-367. 
Gurtner F. (2004), "Why Did Argentina's Currency Board Collapse?", The World Economy, Vol. 27, No. 5, pp. 679-697.

Gutierrez, J and Montes-Negret, F., (2004) “Argentina's Banking System: Restoring Financial Viability", World Bank Working Paper N.2/04.

Hausmann, R. and A. Velasco, "The Argentine collapse: hard money's soft underbelly: Understanding the Argentine Crisis," in Brookings Trade Forum: 2002, edited by S. Collins and D. Rodrik, Washington. D.C.

IMF (2003) "Lessons from the Crisis in Argentina", http://www.imf.org/external/np/pdr/lessons/100803.pdf

IMF (2004) “The IMF and Argentina, 1991-2001”, Independent Evaluation Office

Levy-Yeyati, E, Schmukler, S. and N. van Horen (2003). The Price of Inconvertible Deposits: The Stock Market Boom During the Argentine Crisis. Economics Letters. Volume 83,1,7-13.

Mendoza E., K. Smith (2002) 'Margin Calls, Trading Costs, And Asset Prices In Emerging Markets: The Financial Mechanics Of The 'Sudden Stop' Phenomenon', NBER Working Paper 9286.

Mussa, M., (2002), Argentina and the Fund: From Triumph to Tragedy. Institute for International Economics, Washington D.C.

Perry, G. and L. Serven, (2002) "The Anatomy of a Multiple Crisis: Why Was Argentina Special and What Can We Learn from it?" World Bank. http://www.nber.org/\%7Econfer/2002/argentina02/perry.pdf

Pou, P., (2000), "Argentina's Structural Reforms of the 1990s", IMF Finance and Development, March, volume 37, number 1.

Randall, L., An Economic History of Argentina in the Twentieth Century, New York: Columbia University Press, 1978.

Reinhart, C., Rogoff, K. and Savastano, (2003) “Debt Intolerance”, NBER working paper 9908.

Rigobon R. (2002), “The Curse Of Non-Investment Grade Countries", Journal of Development Economics, vol 69, issue 2, December, 423-449.

Romero, L. A. and J. Brennan, A History of Argentina in the Twentieth Century, Penn State University Press, University Park, PA, 2002. 
Taylor, Alan. M., (1998) "Argentina and the World Capital Market: Saving, Investment and International Capital Mobility in the Twentieth Century," Journal of Development Economics, 57, October, 147-84.

Tommasi, M. (2002) "Federalism in Argentina and the Reforms of the 1990s," Working paper. 


\section{Appendix: Argentina's Financial Market Event Time Line}

\begin{tabular}{|c|c|}
\hline 1989 & \\
\hline July 9 & $\begin{array}{l}\text { Carlos Menem assumed the Argentine presidency in the first peaceful } \\
\text { transfer of power from one democratically elected leader to another } \\
\text { since } 1928 \text {. }\end{array}$ \\
\hline November & $\begin{array}{l}\text { New Foreign Investment Regime put into place. All legal limits on } \\
\text { foreign investment abolished. Capital gains and dividends can now be } \\
\text { repatriated freely. No need for previous approval of transactions. No } \\
\text { legal limits regarding type or nature of foreign investment. Introduction } \\
\text { of a free exchange rate regime. Bekaert and Harvey official } \\
\text { liberalization date. }\end{array}$ \\
\hline December & $\begin{array}{l}\text { The exchange system was again unified for all dealings under a Free } \\
\text { Floating Rate and the currency unit depreciated. Dual export rates still } \\
\text { exist. }\end{array}$ \\
\hline 1990 & \\
\hline March & $\begin{array}{l}\text { Currency made fully convertible. Foreign portfolio investment by } \\
\text { Argentine residents now possible. }\end{array}$ \\
\hline November & $\begin{array}{l}\text { Menem extends value added tax to services, implements tax on fixed } \\
\text { assets }\end{array}$ \\
\hline 1991 & \\
\hline March 22 & Export taxes are eliminated, abolishing the dual export rates. \\
\hline April 1 & $\begin{array}{l}\text { Argentina's Congress enacts the Convertibility Law, which legally } \\
\text { adopts the currency board guaranteeing the convertibility of peso } \\
\text { currency to dollars at a one-to-one fixed rate and limiting the printing of } \\
\text { pesos only to an amount necessary to purchase dollars in the foreign } \\
\text { exchange market. Effectively, each peso in circulation is backed by a } \\
\text { U.S. dollar and monetary policy is forcibly constrained to uphold that } \\
\text { promise. }\end{array}$ \\
\hline August & Law protecting dollar denominated deposits enacted. \\
\hline October & $\begin{array}{l}\text { Argentine Fund begins. This fund marks the first time US investors can } \\
\text { invest in a mutual fund that represents a broad part of the market. } \\
\text { Deregulation decree reformed domestic industry, external trade, and } \\
\text { capital markets. The deregulation decree eliminates capital gains taxes } \\
\text { for foreigners. }\end{array}$ \\
\hline 1992 & $\begin{array}{l}\text { Argentina enjoys strong economic growth and the currency board is } \\
\text { considered highly successful. }\end{array}$ \\
\hline January & $\begin{array}{l}\text { Austral replaced by peso. All transactions in currency can now be made } \\
\text { on the free market at free negotiated rates. }\end{array}$ \\
\hline July & Moody's upgrades Argentina's sovereign debt rating from B3 to B1. \\
\hline 1993 & $\begin{array}{l}\text { The economy soars, at an annual growth rate above } 5.5 \text { percent, as } \\
\text { inflation subsides and the government embarks on an ambitious program } \\
\text { of deregulation, lowering trade barriers and privatizing state-owned } \\
\text { enterprises including oil, telephones and power. }\end{array}$ \\
\hline March & Social security reform (announcement of creation of private pension \\
\hline
\end{tabular}




\begin{tabular}{|c|c|}
\hline & $\begin{array}{l}\text { fund system to begin operation in future). Argentina's Comission de } \\
\text { Valores stipulates that only financial intermediary firms belonging to } \\
\text { self-regulating organizations can participate in public offering of } \\
\text { securities. This move attempts to cut down on insider trading on the } \\
\text { Buenos Aires exchange. }\end{array}$ \\
\hline April 7 & $\begin{array}{l}\text { Swaps of bonds for eligible debts agreed to under the Brady Plan by } \\
\text { Argentina and foreign creditor banks began to take place in accordance } \\
\text { with the debt- and debt-service-reduction operations. }\end{array}$ \\
\hline May & $\begin{array}{l}\text { Import tariffs on capital goods abolished and a } 15 \% \text { tax reimbursement } \\
\text { to capital goods producers established. }\end{array}$ \\
\hline August & S\&P assigns first time rating of BB- to sovereign debt. \\
\hline \multicolumn{2}{|r|}{ ( } \\
\hline March 28 & $\begin{array}{l}\text { Swaps of bonds for eligible debts agreed to under the Brady Plan by } \\
\text { Argentina and foreign creditor banks are completed. }\end{array}$ \\
\hline August & First T-bill auction in 20 years held. \\
\hline December 20 & $\begin{array}{l}\text { Mexican peso devaluation was followed by a withdrawal of foreign } \\
\text { investors from Latin American countries, leading to banking crises: } \\
\text { eight banks were suspended and three banks collapsed. Events } \\
\text { weakened position of wholesale banks that had significant inventories of } \\
\text { government securities on which they were incurring capital losses due to } \\
\text { the increase in interest rates. Non-financial firms were affected as well. } \\
\text { Central Bank provided emergency liquidity assistance. }\end{array}$ \\
\hline December 28 & $\begin{array}{l}\text { Reserve requirements reduced on dollar deposits in order to provide } \\
\text { more liquidity to the banking system. }\end{array}$ \\
\hline 1995 & $\begin{array}{l}\text { Following Mexico's December } 1994 \text { peso devaluation, capital flows out } \\
\text { of emerging markets. Argentina's GDP declines by } 2.8 \% \text {. }\end{array}$ \\
\hline January 1 & $\begin{array}{l}\text { The Treaty of Asuncion (1991), establishing the Southern Core } \\
\text { Common Market (MERCOSUR) became effective. }\end{array}$ \\
\hline January 15 & $\begin{array}{l}\text { Reserve requirements on peso deposits lowered and a special security } \\
\text { fund managed by Banco Nacion set up to assist institutions which } \\
\text { suffered high deposit withdrawals. }\end{array}$ \\
\hline February & $\begin{array}{l}\text { Trust Fund for Provincial Development set up to help support Provincial } \\
\text { Banks. }\end{array}$ \\
\hline March & $\begin{array}{l}\text { Tax of } 3 \text { percent was reimposed on all imports, with the exception of } \\
\text { capital goods, fuel, and goods produced in the paper, computer, and } \\
\text { telecommunications sectors. All goods imported from the member } \\
\text { countries of MERCOSUR were also exempted. Trust Fund for Bank } \\
\text { Capitalization established and changes made to the Central Bank charter } \\
\text { to allow it to use repos and rediscounts to help troubled banks. New loan } \\
\text { agreements made with the IMF, World Bank and IBD and issuance of } \\
\text { new bonds to increase international reserves and fund the trust funds. }\end{array}$ \\
\hline April & $\begin{array}{l}\text { A limited system of deposit insurance was introduced in response to the } \\
\text { banking crisis. Provincial sales tax considered in exchange for lower } \\
\text { social security contributions. }\end{array}$ \\
\hline May & $\begin{array}{l}\text { New rules for bank reserve requirements implemented. President } \\
\text { Menem is reelected President after convincing Congress to change }\end{array}$ \\
\hline
\end{tabular}




\begin{tabular}{|c|c|}
\hline & electoral laws that prohibit a second term. \\
\hline August & $\begin{array}{l}\text { Bank reserve requirement for checking and savings accounts lowered } \\
\text { from } 33 \% \text { to } 30 \% \text { and the } 2 \% \text { reserve requirement for time deposits is } \\
\text { eliminated. }\end{array}$ \\
\hline 1996 & $\begin{array}{l}\text { The central bank announced the creation of a } \$ 6 \text { billion emergency fund } \\
\text { to strengthen the banking sector. Labor reform allows companies to } \\
\text { reduce payroll expenses by firing workers without severance pay. }\end{array}$ \\
\hline July 26 & Finance Minister Domingo Cavallo is dismissed. \\
\hline August & $\begin{array}{l}\text { Tax increases on fuel and public transportation. Government announces } \\
\text { plans to increase personal asset tax on holdings over } \$ 100,000 \text { to } 1 \% \text {. }\end{array}$ \\
\hline September & Economic hardship leads to a general strike. \\
\hline 1997 & $\begin{array}{l}\text { Removal of most entry barriers and branching restrictions of the banking } \\
\text { sector. }\end{array}$ \\
\hline April & $\begin{array}{l}\text { Standard and Poor's raises sovereign debt rating to BB and upgrades } 13 \\
\text { private companies to investment grade. }\end{array}$ \\
\hline July & East Asian financial crisis begins. \\
\hline 1998 & $\begin{array}{l}\text { Argentina enters prolonged recession in third quarter and unemployment } \\
\text { begins to rise. }\end{array}$ \\
\hline February & $\begin{array}{l}\text { The IMF approves a three-year } \$ 2.8 \text { billion line of credit to support } \\
\text { Argentina's economic reform program. The major tax package would } \\
\text { reduce by } 50 \% \text { the VAT tax on basic consumer goods. The top } \\
\text { corporate tax rate would boost to } 35 \% \text { from } 33 \% \text { and reduce by } 10 \% \text { the } \\
\text { social security contributions by employers. }\end{array}$ \\
\hline August & Russia announces a partial default on its sovereign bonds. \\
\hline \multicolumn{2}{|r|}{ e } \\
\hline January 13 & Brazil devalues its currency. \\
\hline September & $\begin{array}{l}\text { The Argentine Congress passes the Fiscal Responsibility Law, } \\
\text { committing to large reductions in both federal and provincial } \\
\text { government spending. }\end{array}$ \\
\hline October 24 & $\begin{array}{l}\text { Fernando de la Rua of the Radical Civic Union (UCR), the opposition } \\
\text { coalition candidate, running on a platform to end corruption (under } \\
\text { Menem) and the recession, defeats Peronist candidate Eduardo Duhalde } \\
\text { for President. De la Rua inherits } 114 \text { billion-dollar public debt. }\end{array}$ \\
\hline December 10 & $\begin{array}{l}\text { De la Rua is inaugurated President of Argentina and shortly thereafter } \\
\text { seeks assistance from the IMF. }\end{array}$ \\
\hline 2000 & $\begin{array}{l}\text { Strikes and fuel tax protests. Beef exports slump after an outbreak of } \\
\text { foot-and-mouth disease. Soya exports suffer from concerns over the use } \\
\text { of genetically modified varieties. }\end{array}$ \\
\hline March 10 & $\begin{array}{l}\text { The IMF agrees to three-year } \$ 7.2 \text { billion stand-by arrangement with } \\
\text { Argentina conditioned on a strict fiscal adjustment and the assumption } \\
\text { of 3.5\% GDP growth in } 2000 \text { (actual growth was } 0.5 \% \text { ). }\end{array}$ \\
\hline May 29 & $\begin{array}{l}\text { The government announces } \$ 1 \text { billion in budget cuts in hopes that fiscal } \\
\text { responsibility will bring renewed confidence to economy. }\end{array}$ \\
\hline December 18 & $\begin{array}{l}\text { The de la Rua government announces a } \$ 40 \text { billion multilateral } \\
\text { assistance package organized by IMF. }\end{array}$ \\
\hline
\end{tabular}




\begin{tabular}{|c|c|}
\hline 2001 & \\
\hline January 12 & $\begin{array}{l}\text { Argentina's continued poor economic performance prompts the IMF to } \\
\text { augment the March 10, } 2000 \text { agreement by } \$ 7.0 \text { billion as part of a } \$ 40 \\
\text { billion assistance package involving the Inter-American Development } \\
\text { Bank, the World Bank, Spain, and private lenders. The agreement } \\
\text { assumes GDP will grow at a rate of } 2.5 \% \text { in } 2001 \text { (versus actual decline } \\
\text { of 5.0\%). }\end{array}$ \\
\hline March 19 & $\begin{array}{l}\text { Domingo Cavallo, Minister of Economy under Menem and architect of } \\
\text { the currency board ten years earlier, replaces Ricardo Lopez Murphy, } \\
\text { who resigns as Minister of Economy. }\end{array}$ \\
\hline March 26-28 & $\begin{array}{l}\text { Risk rating agencies lower Argentina's long-term sovereign rating (S\&P } \\
\text { from BB to B+ and Moody's from B1 to B2). }\end{array}$ \\
\hline March 28 & $\begin{array}{l}\text { Minister Cavallo secures "emergency powers" from Congress. Cavallo } \\
\text { announces economic program comprising a tax on bank transactions, } \\
\text { changes in other taxes and tariffs, and sectoral "competitiveness plans." }\end{array}$ \\
\hline April & $\begin{array}{l}\text { Central bank reduces liquidity requirements and allows banks to include } \\
\text { government securities up to Arg } \$ 2 \text { billion among liquidity requirements. }\end{array}$ \\
\hline May 8 & $\begin{array}{l}\text { Standard \& Poor’s lowers Argentina’s long-term sovereign rating } \\
\text { further from B+ to B. }\end{array}$ \\
\hline June 3 & $\begin{array}{l}\text { Authorities announce the completion of the "mega-swap." Government } \\
\text { bonds with a face value of US } \$ 29.5 \text { billion are voluntarily exchanged } \\
\text { for longer-term instruments. }\end{array}$ \\
\hline June 15 & $\begin{array}{l}\text { Minister Cavallo announces package of tax and trade measures, } \\
\text { including a trade compensation mechanism for exporters and importers } \\
\text { of non-energy goods. }\end{array}$ \\
\hline June 16-17 & $\begin{array}{l}\text { The de la Rua government announces a } \$ 29.5 \text { billion voluntary debt } \\
\text { restructuring in which short-term debt is exchanged for new debt with } \\
\text { longer maturities and higher interest rates. }\end{array}$ \\
\hline June 19 & $\begin{array}{l}\text { The peso exchange rate for merchandise trade is priced at a } 50 / 50 \text { dollar- } \\
\text { euro peg, effectively allowing a } 7 \% \text { devaluation for foreign trade in } \\
\text { hopes of improving Argentina's international competitiveness. Many } \\
\text { analysts raise concern over the effects on the credibility of the } \\
\text { convertibility regime. }\end{array}$ \\
\hline July & $\begin{array}{l}\text { Much of the country is brought to a standstill by a general strike in } \\
\text { protest against proposed government spending cuts. Risk rating agencies } \\
\text { lower Argentina's long-term sovereign rating further (S\&P from B to B- } \\
\text { and Moody's first from B2 to B } 3 \text { and then from B } 3 \text { to Caa1). }\end{array}$ \\
\hline July 10 & $\begin{array}{l}\text { Government pays yield of } 14.1 \text { percent to place US } \$ 827 \text { million of } 90- \\
\text { day } 8 \text { paper. }\end{array}$ \\
\hline July 11 & $\begin{array}{l}\text { Minister Cavallo announces drastic program of fiscal adjustment aimed } \\
\text { at eliminating the federal government deficit from August } 2001 \text { onwards } \\
\text { (the "zero-deficit plan"). }\end{array}$ \\
\hline July 30 & $\begin{array}{l}\text { Senate approves the zero-deficit plan (lower house of Congress had } \\
\text { approved it on July 20). }\end{array}$ \\
\hline August 21 & $\begin{array}{l}\text { IMF announces likely US } \$ 8 \text { billion augmentation of Argentina's stand- } \\
\text { by credit. }\end{array}$ \\
\hline
\end{tabular}




\begin{tabular}{|c|c|}
\hline September 7 & $\begin{array}{l}\text { IMF approves augmentation of stand-by credit to about US\$21.6 billion } \\
\text { and completes Fourth Review. }\end{array}$ \\
\hline September 20 & $\begin{array}{l}\text { The Central Bank activates the contingent repo facility with } \\
\text { international banks, boosting gross reserves by about US } \$ 1.2 \text { billion } \\
\text { (US } \$ 500 \text { million was disbursed in October). }\end{array}$ \\
\hline October 9-12 & $\begin{array}{l}\text { Risk rating agencies lower Argentina's long-term sovereign rating } \\
\text { further (S\&Pfrom B- to CCC and Moody's from Caa1 to Caa3). }\end{array}$ \\
\hline October 12 & $\begin{array}{l}\text { Moody's lowers Argentina's long-term sovereign rating from Caa1 to } \\
\text { Caa3. }\end{array}$ \\
\hline October 16 & $\begin{array}{l}\text { Pre-set date for Congressional elections. The opposition Peronists take } \\
\text { control of both houses of Parliament. Cavallo and financial markets } \\
\text { (erroneously) expected that a fiscal deal could be worked out after the } \\
\text { elections (on the } 17^{\text {th }} \text { ). }\end{array}$ \\
\hline October 28 & $\begin{array}{l}\text { Minister Cavallo starts negotiations with the IMF and the U.S. Treasury } \\
\text { to purchase collateral for new Argentine bonds to be issued in an } \\
\text { exchange for the nearly } \$ 100 \text { billion of local and external debt. }\end{array}$ \\
\hline October 29 & $\begin{array}{l}\text { Mr. Cavallo defines the debt exchange operation as voluntary. The old } \\
\text { debt would exchange for bonds paying seven percent per year and be } \\
\text { guaranteed by tax revenues. The IMF and U.S. Treasury require } \\
\text { compliance with a zero deficit and an agreement with the provinces on } \\
\text { tax revenue sharing before any kind of financial support is given. }\end{array}$ \\
\hline October 30 & $\begin{array}{l}\text { Standard \& Poor's lowers Argentina's long-term sovereign rating from } \\
\text { CCC+ to CC. }\end{array}$ \\
\hline November 1 & $\begin{array}{l}\text { The authorities announce a new fiscal package, including a new batch of } \\
\text { competitiveness plans, the rebate of VAT payments on debit card } \\
\text { transactions, a temporary reduction in employee social security } \\
\text { contributions, a corporate debt restructuring scheme, and a tax amnesty } \\
\text { that writes off interest and penalty obligations accrued to end-September } \\
2001 \text {. }\end{array}$ \\
\hline November 6 & $\begin{array}{l}\text { Standard \& Poor's lowers Argentina's long-term sovereign rating from } \\
\text { CC to SD (selective default). Argentina conducts a second debt swap, } \\
\text { exchanging } \$ 60 \text { billion of bonds with an average interest rate of } 11-12 \% \\
\text { for extended maturity notes carrying only } 7 \% \text { interest rate. International } \\
\text { bond rating agencies consider it an effective default. }\end{array}$ \\
\hline November 19 & $\begin{array}{l}\text { The IMF announces it will not make any new disbursements without } \\
\text { being satisfied that Argentina has secured the goals previously } \\
\text { designated. }\end{array}$ \\
\hline November 23 & $\begin{array}{l}\text { The Central Bank introduces an effective cap on bank deposits, by } \\
\text { imposing a } 100 \text { percent liquidity requirement on deposits paying an } \\
\text { interest rate more than } 1 \text { percentage point above average of all local } \\
\text { banks. }\end{array}$ \\
\hline November 30 & $\begin{array}{l}\text { End of a debt swap with local banks and pension funds for more that } 55 \\
\text { billion (over a total public debt of } 160 \text { billions). The authorities } \\
\text { announce completion of the local-leg of the debt restructuring. } \\
\text { Government bonds with a face value of US } \$ 41 \text { billion at the Federal } \\
\text { level and US10 billion at the provincial level are "voluntarily" }\end{array}$ \\
\hline
\end{tabular}




\begin{tabular}{|c|c|}
\hline & exchanged. \\
\hline December & $\begin{array}{l}\text { Economy Minister Cavallo announces sweeping restrictions to halt an } \\
\text { exodus of bank deposits. The IMF stops } \$ 1.3 \mathrm{bn} \text { in aid. }\end{array}$ \\
\hline December 2 & $\begin{array}{l}\text { The government announces temporary capital control regime (termed } \\
\text { Corralito) involving bank withdrawal limits and limits on dollar } \\
\text { transfers abroad as a last-ditch effort to fend off a devaluation and } \\
\text { prevent a major banking crisis. Withdrawals are limited to } 250 \text { pesos } \\
\text { (dollars) per week per account. Depositors, however, may still access } \\
\text { funds for larger purchases through checks or debit cards and transfer } \\
\text { their money among banks. Holders of deposits may also exchange them } \\
\text { for federal bonds (BODENs) maturing in } 2005,2007 \text { or } 2012 \text { in a Canje } \\
\text { exchange. No limits are placed on domestic payments made with } \\
\text { checks, credits, debit cards and electronic MEP (Metodo Electronico de } \\
\text { Pagos) payments. }\end{array}$ \\
\hline December 3 & $\begin{array}{l}\text { The capital control measures announced on Dec } 2 \text { nd come into full } \\
\text { effect through Decree } 1570-01 \text { on Dec } 3^{\text {rd. }} \\
\text { a) Wire transfers suspended except with prior Central Bank approval. } \\
\text { b) Cash withdrawals from the Banking System limited to US } \$ 1000 \text { per } \\
\text { month. } \\
\text { c) Financial Argentine institutions prohibited from foreign currency } \\
\text { futures transactions. } \\
\text { d) Financial Argentine institutions prohibited from issuing new bank } \\
\text { loans denominated in Argentine Pesos. All new loans must be issued in } \\
\text { U.S. dollars and existing peso loans must be converted to U.S. dollar } \\
\text { loans at a one to one rate. } \\
\text { e) Foreign investors trading in the Argentine Securities Market subject } \\
\text { to repatriation restrictions. Funds related to securities transactions must } \\
\text { remain in the country until government approval is obtained or the } \\
\text { measure is officially revoked. }\end{array}$ \\
\hline December 5 & $\begin{array}{l}\text { The IMF withholds } \$ 1.24 \text { billion loan installment, citing Argentina's } \\
\text { repeated inability to meet fiscal targets. }\end{array}$ \\
\hline December 7 & $\begin{array}{l}\text { Argentina announces it can no longer guarantee payment on foreign } \\
\text { debt. }\end{array}$ \\
\hline December 10 & $\begin{array}{l}\text { The BCRA imposes a } 98 \text { percent reserve requirement on deposit } \\
\text { increases after December 1, 2001; aimed at limiting flight to quality } \\
\text { within the system. }\end{array}$ \\
\hline December 13 & $\begin{array}{l}\text { A 24-hour general strike is held in protest at curbs on bank withdrawals, } \\
\text { delayed pension payouts and other measures. Phase one of the } \\
\text { government debt exchange is completed. }\end{array}$ \\
\hline December 19 & $\begin{array}{l}\text { State of emergency is declared to stop protests against Minister } \\
\text { Cavallo's economic policies. The lower house of Congress repeals the } \\
\text { special legislative powers granted to Cavallo. }\end{array}$ \\
\hline December 20 & $\begin{array}{l}\text { President Dela Rua and Minister Cavallo resign after days of riots and } \\
\text { protests that leave over } 20 \text { demonstrators dead. A banking holiday is } \\
\text { declared for December } 21 \text {, extended through December 26. Moody's } \\
\text { lowers Argentina ratings to Ca from Caa3. Mr. Ramon Puerta becomes }\end{array}$ \\
\hline
\end{tabular}




\begin{tabular}{|c|c|}
\hline & $\begin{array}{l}\text { interim president. Country Risk reaches } 4618 \text { points. Global (sovereign) } \\
\text { bond yields reach their historical maximum of } 49 \% \text { annual return in } \\
\text { dollars. }\end{array}$ \\
\hline December 21 & The official Foreign Exchange Rate market is closed. \\
\hline December 23 & $\begin{array}{l}\text { Mr. Rodriguez Saa becomes the new interim president for } 60 \text { days. He } \\
\text { declares the suspension of external debt payments for at least } 60 \text { days, } \\
\text { totaling } \$ 166 \text { bn in federal and provincial debt. }\end{array}$ \\
\hline December 24 & $\begin{array}{l}\text { The government announces that a new fiat currency (i.e., without } \\
\text { foreign-currency backing) will be created (the argentino). }\end{array}$ \\
\hline December 26 & $\begin{array}{l}\text { The liquidity standards for banks are relaxed. Rodriguez Saa announces } \\
\text { a new economic plan based on: 1) suspension of payments on public } \\
\text { debt; 2) new jobs creation program; and 3) creation of new currency (the } \\
\text { Argentino) to begin circulating in January } 2002 \text { and not to be } \\
\text { convertible to the U.S. dollar. }\end{array}$ \\
\hline December 30 & $\begin{array}{l}\text { President Saá resigns after his emergency policies are rejected by the } \\
\text { Peronist governors. }\end{array}$ \\
\hline \multicolumn{2}{|r|}{ ( } \\
\hline January 1 & $\begin{array}{l}\text { Congress elects Peronist Senator Eduardo Duhalde as caretaker } \\
\text { president. }\end{array}$ \\
\hline January 3 & $\begin{array}{l}\text { Senator Duhalde is sworn-in as President with a mandate to conclude } \\
\text { the remaining period of the de la Rúa presidency; President Duhalde } \\
\text { announces the end of convertibility, and the introduction of a dual } \\
\text { foreign exchange regime. }\end{array}$ \\
\hline January 4 & $\begin{array}{l}\text { "Leak" reported in the financial press suggests that a } 40 \% \text { devaluation is } \\
\text { imminent. }\end{array}$ \\
\hline January 5 & The Argentine stock market is closed. \\
\hline January 6 & $\begin{array}{l}\text { The Argentine Congress votes to establish the Law of Economic } \\
\text { Emergency and abolish the Convertibility Law. After the Argentine } \\
\text { Congress passes necessary legislation, President Duhalde announces the } \\
\text { end of the currency board and a plan to devalue the peso by } 29 \% \text { (to } 1.4 \\
\text { to the dollar) for major foreign commercial transactions, with a floating } \\
\text { rate for all other transactions. Other elements of economic plan include: } \\
\text { converting all debts up to } \$ 100,000 \text { to pesos (passing on devaluation } \\
\text { cost to creditors); capital and bank account controls; a new tax on oil to } \\
\text { compensate creditors for the losses that will ensue; renegotiating public } \\
\text { debt, and a balanced budget. }\end{array}$ \\
\hline January 7 & $\begin{array}{l}\text { The new Minister of Finance, Mr. Lenicov, announces the devaluation } \\
\text { of the peso and the establishment of a new dual foreign exchange rate } \\
\text { regime, to be implemented on the } 9^{\text {th }} \text { of January, } 2002 \text {. }\end{array}$ \\
\hline January 10 & $\begin{array}{l}\text { Government announces it will "guarantee" dollar deposits, but to curtail } \\
\text { bank runs, the } \$ 1,000(1,500 \text { peso) limit on monthly withdrawals is } \\
\text { maintained and all checking and savings accounts with balances } \\
\text { exceeding } \$ 10,000 \text { and } \$ 3,000 \text {, respectively, will be converted to } \\
\text { certificates of deposit and remain frozen for at least one year. Smaller } \\
\text { deposits have the option of earlier withdrawal by moving to peso } \\
\text { denominated accounts at the } 1.4 \text { exchange rate. }\end{array}$ \\
\hline
\end{tabular}




\begin{tabular}{|c|c|}
\hline January 11 & $\begin{array}{l}\text { After several delays, the exchange rate market re-opens and the new } \\
\text { dual exchange rate system is put in place: } \\
\text { a) } 1 \text { Argentinean peso= } 1 \text { U.S. dollar parity (Convertibility Plan) is } \\
\text { abolished. } \\
\text { b) All debts (capital and interests) agreed in ARG currency with } \\
\text { financial entities - converted into U.S. dollars according to the Decree } \\
1570 / 2001 \text { - will be reconverted into the original currency agreed } \\
\text { (pesos). } \\
\text { c) The official, fixed conversion rate of } 1 \text { U.S Dollar=1.4 pesos is } \\
\text { relevant for foreign trade operations. The free or floating rate is relevant } \\
\text { for all other transactions and freely determined by the market. }\end{array}$ \\
\hline January 16 & $\begin{array}{l}\text { The IMF approves request for one-year extension on } \$ 936 \text { million } \\
\text { payment due January } 17 \text {, keeping Argentina from falling into arrears. }\end{array}$ \\
\hline January 17 & $\begin{array}{l}\text { Argentine stock market re-opens. The government announces that } \\
\text { dollar denominated loans exceeding } \$ 100,000 \text { will be converted to pesos } \\
\text { at } 1.4 \text { for fixed rate, deepening the balance sheet mismatch of banks. }\end{array}$ \\
\hline January $19-20$ & $\begin{array}{l}\text { Duhalde reverses his decision to guarantee dollar deposits, which will be } \\
\text { converted to pesos at some undefined devalued exchange rate. }\end{array}$ \\
\hline January 21 & $\begin{array}{l}\text { The government announces the easing of bank withdrawal restrictions: } \\
\text { a) Up to 7,000 pesos can be withdrawn from term deposits in pesos } \\
\text { (transferring that money to a checking account) } \\
\text { b) Up to 5,000 dollars can be withdrawn from term deposits in dollars } \\
\text { (transferring that money to a checking account at the official exchange } \\
\text { rate, } 1.40 \text { ). } \\
\text { c) Up to 5,000 dollars in a saving account can be pesofied at the official } \\
\text { exchange rate. }\end{array}$ \\
\hline January 23 & $\begin{array}{l}\text { The Argentine Senate passes bankruptcy law that would use capital } \\
\text { controls to restrict payment of foreign private debt payments through } \\
\text { December } 2003 \text {. }\end{array}$ \\
\hline January 24 & Utility tariffs are frozen indefinitely. \\
\hline January 30 & $\begin{array}{l}\text { Argentina's Chamber of Deputies passes controversial bankruptcy law, } \\
\text { stripping it of the Senate provision prohibiting foreign debt payments, } \\
\text { but other capital controls remain in effect. It retains language allowing } \\
\text { conversion of dollar denominated debt below } \$ 100,000 \text { to pesos at } 1 \text {-to- } \\
1 \text { rate (benefitting debtors) and suspending creditor action on loan debt } \\
\text { defaults for } 180 \text { days. }\end{array}$ \\
\hline February 3 & $\begin{array}{l}\text { Mr. Lenicov announces an asymmetric pesofication and the end of the } \\
\text { dual exchange rate regime: } \\
\text { a) pesofication of all dollar deposits at } 1.4 \text { pesos per dollar. } \\
\text { b) corporate and consumer debts are also pesofied, but at the exchange } \\
\text { rate prevailing during the Convertibility period. Both deposits and credit } \\
\text { will be indexed to inflation. } \\
\text { c) the end of the dual exchange rate regime and a unified floating } \\
\text { exchange rate determined by market forces. } \\
\text { d) the right to withdraw wage and pension income from the Corralito }\end{array}$ \\
\hline
\end{tabular}




\begin{tabular}{|c|c|}
\hline & $\begin{array}{l}\text { without any amount restrictions (before workers could only extract up to } \\
1.500 \text { pesos). } \\
\text { Corralon starts which freezes bank term deposits (holders of term } \\
\text { deposits had the option to convert them into CEDROs or BODENs } \\
\text { maturing in } 2007 \text { or } 2012 \text { in a Canje exchange). }\end{array}$ \\
\hline February 4 & $\begin{array}{l}\text { The government decrees the unification of the exchange rate regime and } \\
\text { the asymmetric pesoization of bank balance sheets (assets at } \\
\text { Arg } \$ 1 / \mathrm{US} \$ 1 \text {, and liabilities at Arg } \$ 1.4 / \mathrm{US} \$ 1 \text { ). The official foreign } \\
\text { exchange market is closed. }\end{array}$ \\
\hline February 11 & $\begin{array}{l}\text { The BCRA establishes a new unified free foreign exchange market, } \\
\text { which replaces the two markets - official and free - implemented in } \\
\text { January. The exchange rate market re-opens and the floating dollar } \\
\text { exchange rate reaches } 2.1 \text { pesos, well below the devaluation } \\
\text { expectations built-into asset prices. }\end{array}$ \\
\hline February 27 & $\begin{array}{l}\text { The federal government and the provincial governors reach agreement } \\
\text { on a temporary revenue sharing arrangement that abolishes the } \\
\text { minimum floor on transfers to the provinces in exchange for: (i) the } \\
\text { broadening of the coparticipation base to include the financial } \\
\text { transactions tax; and (ii) better terms for their debt servicing. The } \\
\text { provinces commit to reduce fiscal deficits by } 60 \text { percent in } 2002 \text { and to } \\
\text { achieve balance in } 2003 \text {. }\end{array}$ \\
\hline March 5 & $\begin{array}{l}\text { Export taxes of } 10 \text { percent and } 5 \text { percent are imposed on primary } \\
\text { products and process agricultural and industrial products, respectively. }\end{array}$ \\
\hline March 8 & The pesoization of government debt under Argentine law is decreed. \\
\hline March 13 & $\begin{array}{l}\text { A voluntary bond swap (Swap I) is decreed authorizing the exchange of } \\
\text { reprogrammed time deposits for government bonds. The decree also } \\
\text { authorized issuance of bonds to banks in compensation for the } \\
\text { asymmetric pesoization of their balance sheets. }\end{array}$ \\
\hline March 25 & $\begin{array}{l}\text { The peso reaches a peak of Arg } \$ 4 \text { per dollar. To contain the } \\
\text { depreciation of the currency, the authorities intervene heavily in the } \\
\text { foreign exchange market (US } \$ 800 \text { million in March), tighten the access } \\
\text { to central bank liquidity assistance (a matching dollar from the parent } \\
\text { being now requested as a condition for assistance to foreign banks), and } \\
\text { introduce a variety of exchange regulations affecting banks, foreign } \\
\text { exchange bureaus, and exporters. Thirteen new regulations are issued on } \\
\text { March } 25 \text { alone, bringing the total for the month of March to about } 50 \text {. }\end{array}$ \\
\hline March 26 & $\begin{array}{l}\text { The Central Bank announces new measures related to foreign exchange } \\
\text { transactions and ADR/CEDEAR conversions aimed at improving the } \\
\text { functioning of the foreign currency market and regulating the buying } \\
\text { and selling of foreign currency by order and for the account of the } \\
\text { Central Bank. The press communication also mentions that there will be } \\
\text { coordination between the Comision Nacional de Valores (CNV) and the } \\
\text { Bolsa de Comercio de Buenos Aires (BCBA) in order to adopt new } \\
\text { measures to regulate capital outflows via ADR and CEDEAR } \\
\text { transactions. }\end{array}$ \\
\hline April & Banking and foreign exchange activity suspended; Duhalde says the \\
\hline
\end{tabular}




\begin{tabular}{|c|c|}
\hline & financial system could collapse. \\
\hline April 9 & $\begin{array}{l}\text { Export taxes on agricultural primary products were increased to } 20-231 / 2 \\
\text { percent. }\end{array}$ \\
\hline April 19 & $\begin{array}{l}\text { The central bank suspends for } 30 \text { days Scotiabank Quilmes. A bank } \\
\text { holiday is declared until Congress approves a solution to the problem of } \\
\text { judicial injunctions (amparos) releasing bank deposits. The authorities } \\
\text { begin working on a plan (the so-called BONEX II plan) to convert } \\
\text { reprogrammed time deposits into government bonds. }\end{array}$ \\
\hline April 20 & $\begin{array}{l}\text { Economy Minister Remes Lenicov presents to congress the BONEX II } \\
\text { plan; the draft law is rejected and Minister Remes resigns. }\end{array}$ \\
\hline April 23 & $\begin{array}{l}\text { President Duhalde reaches agreement with provincial governors on a 14- } \\
\text { point Federal-Provincial Pact. }\end{array}$ \\
\hline April 25 & $\begin{array}{l}\text { Congress approves the Ley Tapón to ease pressure from the amparos. } \\
\text { The law modifies court procedures, and states that depositors can only } \\
\text { access funds once the judicial process is over; in the meantime funds are } \\
\text { deposited in an escrow account. }\end{array}$ \\
\hline May 6 & The Federal Congress approves the February Federal-Provincial Pact. \\
\hline May 15 & $\begin{array}{l}\text { Congress approves law that reverses the most harmful provisions of the } \\
\text { January emergency law and makes limited improvements to the } \\
\text { insolvency law. }\end{array}$ \\
\hline May 30 & The Economic Subversion Law is repealed. \\
\hline May 31 & $\begin{array}{l}\text { In order to tighten the control over the sale of export receipts, the central } \\
\text { bank announced that dollar export revenues in excess of US } \$ 1 \text { million } \\
\text { will have be sold directly to the central bank. Province of Buenos Aires } \\
\text { and Federal government sign full-fledged text of Bilateral Agreement. } \\
\text { Agreement on the Annexes (quarterly fiscal targets and calendar for } \\
\text { disbursement) is reached in June. }\end{array}$ \\
\hline June 1 & $\begin{array}{l}\text { President Duhalde signs the Options Plan on reprogrammed deposits, a } \\
\text { revised version offormer Minister Remes' BONEX II Plan, giving } \\
\text { depositors the option to exchange deposits into bonds. }\end{array}$ \\
\hline June 18 & $\begin{array}{l}\text { The minimum level of export proceeds that should be surrendered to the } \\
\text { central bank lowered from US } \$ 1 \text { million to US } \$ 500,000 \text {. }\end{array}$ \\
\hline July & $\begin{array}{l}\text { Duhalde calls early elections for March 2003, later put back to April, to } \\
\text { try win public support for the government's handling of the economic } \\
\text { crisis. }\end{array}$ \\
\hline July 9 & $\begin{array}{l}\text { In response to a class action suit lodged by the country's ombudsman on } \\
\text { behalf of all depositors, a federal court declared the deposit freeze and } \\
\text { pesoization unconstitutional. }\end{array}$ \\
\hline July 24 & $\begin{array}{l}\text { The government issued a decree suspending court ordered withdrawals } \\
\text { of frozen bank deposits for } 120 \text { business days. }\end{array}$ \\
\hline July 25 & $\begin{array}{l}\text { The decree suspending deposit withdrawals obtained through court } \\
\text { orders is declared partially unconstitutional by a federal judge. }\end{array}$ \\
\hline July 26 & $\begin{array}{l}\text { Following a demand by the national ombudsman a judge rules } \\
\text { unconstitutional the government decree suspending lawsuits on } \\
\text { December's bank curbs for } 120 \text { business days. }\end{array}$ \\
\hline July 29 & A panel of monetary policy experts made public several proposals to \\
\hline
\end{tabular}




\begin{tabular}{|c|c|}
\hline & $\begin{array}{l}\text { resolve the country's financial crisis including a monetary policy } \\
\text { anchor, an independent central bank, the ending of peso printing deficit- } \\
\text { financing, and an end to the use of quasi-currencies by the provinces. } \\
\text { The report calls for a floating exchange rate and urges Argentina to stop } \\
\text { using international reserves to support the peso. }\end{array}$ \\
\hline August 15 & $\begin{array}{l}\text { Congress approves a bill extending for } 90 \text { days (through mid-November } \\
2002 \text { ) the provision that suspends certain kinds of creditor-initiated } \\
\text { nonbankruptcy law enforcement actions. Congress also approves a bill } \\
\text { extending for } 60 \text { days (through end-September 2002) the application of } \\
\text { price indexation to loans. }\end{array}$ \\
\hline August 22 & $\begin{array}{l}\text { The Supreme Court declares unconstitutional the } 13 \text { percent salary cut } \\
\text { for federal government workers and pensioners, implemented from July } \\
2001 \text {. }\end{array}$ \\
\hline August 26 & $\begin{array}{l}\text { The government issues a resolution to allow the issuance of bank- } \\
\text { compensation bonds for the asymmetric pesoization. }\end{array}$ \\
\hline August 28 & $\begin{array}{l}\text { A federal court establishes that parent banks should be fully responsible } \\
\text { for the liabilities of subsidiaries in Argentina. }\end{array}$ \\
\hline September & $\begin{array}{l}\text { The central bank passed a very restrictive regulation (circular \#3723) } \\
\text { that mandated that every stock be traded in its underlying currency. } \\
\text { After intense opposition from the financial community, the central bank } \\
\text { rescinded \#3723 and instead passed a resolution (circular \#3727) that } \\
\text { forbids "contra cable" operations. These operations allowed brokers to } \\
\text { sell stocks purchased in Buenos Aires instantaneously in New York (or } \\
\text { any foreign market) using the Mercado de Valores as a clearinghouse. } \\
\text { Under \#3727 it was still possible for investors in Argentina to convert } \\
\text { CEDEARs and sell them in New York, but this new restriction } \\
\text { significantly increased the transactions costs to do so. }\end{array}$ \\
\hline September 3 & $\begin{array}{l}\text { The government introduces new exchange controls in an attempt to } \\
\text { boost international reserves and defend the peso: (i) the limit for } \\
\text { exporters' foreign exchange surrender to the central bank is reduced } \\
\text { from US } \$ 500,000 \text { to US } \$ 200,000 \text {; (ii) the minimum maturity of external } \\
\text { debt contracted by private nonfinancial entities is set to } 90 \text { days; ( } 3 \text { ) } \\
\text { exchange bureaus are required to deposit with the central bank foreign } \\
\text { exchange holdings exceeding US } \$ 1.5 \text { million on a daily basis; and (4) } \\
\text { the net dollar positions held by exchange dealers operating on behalf of } \\
\text { the central bank are reduced by an average } 40 \text { percent. }\end{array}$ \\
\hline September 5 & $\begin{array}{l}\text { The federal administrative dispute chamber, an appellate court, rules } \\
\text { that the decrees establishing the corralito and pesoization, were } \\
\text { unconstitutional. The ruling applies to only one case, but opens the door } \\
\text { for further similar rulings. }\end{array}$ \\
\hline September 9 & $\begin{array}{l}\text { Further tightening of foreign exchange controls: prior authorization from } \\
\text { the central bank for dollar purchases exceeding US } \$ 100,000 \text { for } \\
\text { portfolio and other financial investments abroad, as well as for the } \\
\text { purchase of foreign banknotes. }\end{array}$ \\
\hline September 13 & $\begin{array}{l}\text { The Federal Court of Appeals declared the corralito, pesoization, and the } \\
120 \text { days suspension of executions against the corralito, }\end{array}$ \\
\hline
\end{tabular}




\begin{tabular}{|c|c|}
\hline & $\begin{array}{l}\text { unconstitutional; the decision allows depositors to claim their deposits in } \\
\text { court immediately. The } 2003 \text { budget was submitted to Congress. }\end{array}$ \\
\hline September 17 & $\begin{array}{l}\text { The government issued a decree that extends the negotiation period for } \\
\text { utility tariffs for another } 120 \text { days with the possibility of a further } 60 \\
\text { days extension. }\end{array}$ \\
\hline September 20 & $\begin{array}{l}\text { The government launched a second swap of bonds for frozen deposits } \\
\text { and announced the easing of restrictions on frozen time-deposits of up to } \\
\text { Arg } \$ 7,000 \text {. }\end{array}$ \\
\hline October 31 & $\begin{array}{l}\text { The monthly cash withdrawal limit on the corralito raised to } \operatorname{Arg} \$ 2,000 \\
\text { from } \operatorname{Arg} \$ 1,200 \text {. }\end{array}$ \\
\hline November & $\begin{array}{l}\text { Argentina defaults on an } \$ 800 \mathrm{~m} \text { debt repayment to the World Bank, } \\
\text { having failed to re-secure IMF aid. The World Bank says it will not } \\
\text { consider new loans for the country. }\end{array}$ \\
\hline November 11 & $\begin{array}{l}\text { After discussions with the government, the banks announced a voluntary } \\
75 \text { day stay on foreclosures. }\end{array}$ \\
\hline November 14 & $\begin{array}{l}\text { The government did not fully meet an } \$ 809 \text { million World Bank debt } \\
\text { payment; only } \$ 79.2 \text { million in interest was paid. President Duhalde } \\
\text { signed a decree lowering the VAT rate by } 2 \text { percentage point }\end{array}$ \\
\hline November 15 & $\begin{array}{l}\text { A lower court suspended the public hearings designed to grant a tariff } \\
\text { increase to the privatized utility companies. }\end{array}$ \\
\hline November 18 & $\begin{array}{l}\text { President Duhalde signed a 12-point agreement with provincial } \\
\text { governors and some key legislators over the new election timetable and } \\
\text { the government's economic policies. }\end{array}$ \\
\hline November 21 & $\begin{array}{l}\text { The Senate approved President Eduardo Duhalde's plans for delaying } \\
\text { the presidential election by a month to April. The first round of } \\
\text { presidential elections is scheduled to be held on April } 27,2003 \text { and will } \\
\text { be followed by a second round on May 10, if necessary. }\end{array}$ \\
\hline November 22 & $\begin{array}{l}\text { The government announced that it will lift the remaining corralito } \\
\text { restrictions on sight accounts effective December } 2 \text {. Term deposits (the } \\
\text { corralón) remain frozen. Minister Lavagna submitted a draft decree to } \\
\text { President Duhalde lifting the tariff rates on electricity and natural gas. } \\
\text { On average, electricity rates will rise } 9.0 \text { percent and natural gas } 7.2 \\
\text { percent. }\end{array}$ \\
\hline November 27 & $\begin{array}{l}\text { Executive decree issued authorizing court imposed stay on foreclosures } \\
\text { for } 30 \text { business days, during which time mediation is required. }\end{array}$ \\
\hline December 2 & Corralito rescinded. \\
\hline December 9 & $\begin{array}{l}\text { The resignation of Central Bank President Pignanelli is accepted by } \\
\text { President Duhalde. }\end{array}$ \\
\hline December 10 & $\begin{array}{l}\text { President Duhalde appointed Mr. Alfonso Prat Gay to be central bank } \\
\text { president. Legislation eliminating the ability of the executive to grant } \\
\text { tax amnesties becomes effective. }\end{array}$ \\
\hline December 11 & A court order reverses the decreed increases in electricity and gas tariffs. \\
\hline \multicolumn{2}{|l|}{2003} \\
\hline March 9 & $\begin{array}{l}\text { The Supreme Court ruled that conversion to pesos was illegal. } \\
\text { According to the Central Bank, approximately to } 8,760 \text { million US } \\
\text { dollars are at stake. }\end{array}$ \\
\hline
\end{tabular}




\begin{tabular}{|l|l|}
\hline May & $\begin{array}{l}\text { Nestor Kirchner sworn in as president. Former President Carlos Menem } \\
\text { gained most votes in first round of elections but pulled out before } \\
\text { second round. }\end{array}$ \\
\hline September 10 & $\begin{array}{l}\text { Argentine finance officials reached an agreement with the International } \\
\text { Monetary Fund (IMF) for a three-year, US\$ } 12.6 \text { billion stand-by credit. } \\
\text { Under the terms of the new arrangement, the government pledges to } \\
\text { raise the consolidated primary fiscal surplus from 2.5\% of GDP this year } \\
\text { to 3.0\% next year. }\end{array}$ \\
\hline Ap04 & $\begin{array}{l}\text { Argentina decided to make a \$3.1 billion payment to the IMF, a retreat } \\
\text { from a vow by Buenos Aires that it would not pay up unless the IMF } \\
\text { sends signals it would approve an upcoming report on Argentina 's } \\
\text { economic progress as part of the 2003 accord. }\end{array}$ \\
\hline July 2 & $\begin{array}{l}\text { Argentina filed a shelf registration statement with the U.S. Securities } \\
\text { and Exchange Commission, completing the documentation needed to } \\
\text { seek regulatory approval in the U.S. for a debt exchange to restructure } \\
\text { some \$100 billion in defaulted debt. }\end{array}$ \\
\hline October 26 & $\begin{array}{l}\text { The Supreme Court ruled that the conversion of fixed-term savings in } \\
\text { dollars to pesos - known as "pesofication" - was legal, relieving the } \\
\text { banks of large potential losses from further injunctions. }\end{array}$ \\
\hline
\end{tabular}

Sources: Ambito Financiero, La Nacion, Clarin, Pictet, IMF (2003), BBC News, Bekaert and Harvey online Chronology. 
National income accounts and Macroeconomic Indicators 1/ Real GDP

GDP growth (\%)

Consumption growth $(\%)$

Investment growth (\%)

Export growth (\%)

Import growth (\%)

Investment (\% GDP)

Current account (\% GDP)

Unemployment rate 11/

Inflation, interest rates, and financial markets

CPI inflation 1/

M3 growth (\%) 2/

age EMBI+ index 3/

International Reserves (ARP mil.) 4/

Real Effective Exchange Rate 5/

Merval Index 6/

Peso (prime) loan rate $1 /$

Spread between peso and USD interest rates (basis points) $1 /$

JP Morgan Sovereign Bond Spread (basis points) 3/

Fiscal measures

Government deficit (\% GDP) $1 /$

Provincial government expenditures (\% GDP) $7 /$

Public debt (\% GDP) 2/

External debt (USD mil.) 8/

Debt (\% exports) 8/

Privatization revenue (ARP mil.) $9 /$

IMF loans (USD mil.) 1/

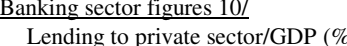

Lending to public sector/GDP (\%)

ARP deposits/GDP (\%)

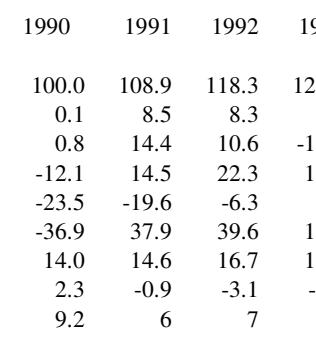

$1993 \quad 1994 \quad 1995$

1996

1997

1998

1999

$\begin{array}{rr}133.8 & 129.0 \\ 6.4 & -3.6\end{array}$

$\begin{array}{lrrr}152.9 & 147.7 & 146.5\end{array}$

$\begin{array}{rr}6.7 & -4.9 \\ 10.2 & -13.5\end{array}$

$\begin{array}{rr}5.3 & 9.0 \\ 6.2 & 14.7\end{array}$

$\begin{array}{rr}14.2 & 22.0 \\ 18.6 & -8.0 \\ 19.9 & 17.9\end{array}$

12.9

9.0
22.1

4.7
9.0
2.1
19.4

$\begin{array}{rrr}3.8 & -3.4 & -0.8 \\ 3.4 & -1.9 & -2.0\end{array}$

$\begin{array}{rrr}6.4 & -13.6 & -11.5 \\ 2.4 & -9.4 & 9.8\end{array}$

$\begin{array}{rrr}5.0 & -14.9 & -0.9\end{array}$

$\begin{array}{rrr}19.9 & 18.0 & 16.2 \\ -4.9 & -4.2 & -3.2 \\ 1.1 & 13.48 & 14.65\end{array}$

13.41

$\begin{array}{llllll}318.4 & 99.9 & 22.2 & 10.1 & 4.1 & 3.3\end{array}$

$0.2 \quad 0.5$

$12.1 \quad 13.48 \quad 14.65$

… $\quad \cdots \quad \cdots$

$\begin{array}{rrrrrrrrrrrr}\ldots & \ldots & \ldots & 10.1 & 17.8 & 10.5 & 9.2 & 10.6 & 11.0 & 11.1 & 27.7 & 51.7\end{array}$

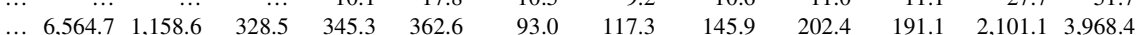

$\begin{array}{llllllll}\cdots & 456.0 & 596.9 & 720.4 & 667.9 & 1.481 .7 & 5,795.1\end{array}$

$\begin{array}{rrrrrrrrrrrrr}-0.3 & -0.5 & 0.0 & -0.6 & -0.7 & -0.6 & -1.9 & -1.5 & -1.4 & -2.9 & -2.4 & -3.3 & -1.1 \\ -9.4 & -10.2 & -11.5 & -12.5 & -12.4 & -12.7 & -11.9 & -11.8 & -12.4 & -13.7 & -13.5 & -14.5 & -11.6\end{array}$

$\begin{array}{rrrrrrrrrrrrr}-9.4 & -10.2 & -11.5 & -12.5 & -12.4 & -12.7 & -11.9 & -11.8 & -12.4 & -13.7 & -13.5 & -14.5 & -11.6 \\ \ldots & \ldots & \ldots & 28.2 & 29.9 & 33.8 & 35.7 & 34.5 & 37.6 & 43.0 & 45.0 & 53.8 & 43.9\end{array}$

$\begin{array}{llllllllllll}62,233 & 65,406 & 68,345 & 64,718 & 75,139 & 98,802 & 111,380 & 128,410 & 141,550 & 145,290 & 145,880 & 136,710\end{array}$

$\begin{array}{llllllllllll}373.7 & 405.4 & 385.3 & 341.1 & 327.9 & 336.0 & 338.9 & 352.2 & 379.4 & 426.6 & 377.6 & 373.7\end{array}$

$\begin{array}{rrrrrr}-257.3 & -589.8 & -73.0 & 1,211.2 & 455.3 & 1,924.1\end{array}$

$\begin{array}{rrrrrrr}374.9 & 21.5 & 96.3 & 2,579.1 & 144.7 & 60.2 & 4.5\end{array}$

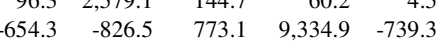

$\begin{array}{rrrrrrrrrrrrr}\ldots & \ldots & \ldots & \ldots & 17.5 & 18.1 & 18.8 & 20.5 & 22.4 & 23.0 & 21.8 & 18.7 & \ldots \\ \ldots & \ldots & \ldots & \ldots & 1.9 & 2.2 & 2.3 & 2.4 & 3.1 & 4.2 & 5.3 & 8.1 & \ldots \\ \ldots & \ldots & \ldots & \ldots & 8.0 & 7.4 & 9.0 & 10.9 & 11.7 & 11.5 & 11.3 & 7.0 & 19.1\end{array}$

0.3 \begin{tabular}{rrr}
136.1 & 147.2 \\
\hline & 5.4 & 7.8
\end{tabular}

$\begin{array}{rrr}-4.1 & -2.0 & -2.5 \\ 12 & 16 & 16.56\end{array}$

$\begin{array}{rrrrr}100.0 & 88.6 & 82.9 & 112.1 & 140.9\end{array}$

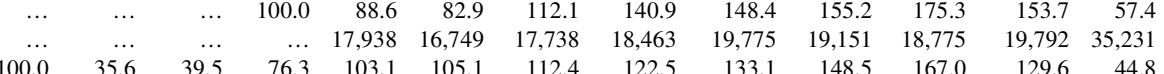

1985-90 1991-94 1995-98 1999-02

$\begin{array}{rrrr}103.3 & 121.6 & 141.3 & 139.8 \\ 0.2 & 5.3 & 4.3 & -4.1 \\ 0.4 & 0.6 & 4.5 & -7.1 \\ -4.0 & 13.7 & 7.1 & -13.5 \\ -2.2 & 4.4 & 6.3 & 24.3 \\ -5.2 & 20.7 & 11.0 & -1.6 \\ 17.0 & 17.6 & 18.8 & 15.1 \\ -1.4 & -2.9 & -3.4 & -1.5 \\ \ldots & 8.5 & 14.5 & 15.9\end{array}$

$\begin{array}{rrrr}396.3 & 9.5 & 0.4 & 5.4 \\ & 0.4 & 13.0 & -7.1\end{array}$

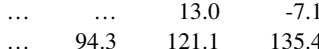

$\begin{array}{lrrr}\text {.. } & 17,938 & 18,181 & 23,237\end{array}$

$\begin{array}{rrrr}\ldots & 63.6 & 118.3 & 122.5\end{array}$

$\begin{array}{rrr}2.099 .3 & 179.7 & 1,615.8\end{array}$

$\begin{array}{lll}\ldots 26.4 & 2,166.3\end{array}$

$\begin{array}{rrrr}-2.1 & -0.5 & -1.3 & -2.4 \\ -9.4 & -11.6 & -12.2 & -13.3\end{array}$

$\begin{array}{rrrr}\ldots & \ldots & 35.4 & 46.4\end{array}$

$\begin{array}{rrrr}58,030 & 68,402 & 120,036 & 142,627\end{array}$

$\begin{array}{llll}535.9 & 365.0 & 351.6 & 392.7\end{array}$

$\begin{array}{rrrr}\ldots & \ldots & 416.0 & 697.1 \\ 173.7 & 250.9 & 399.9 & 2,135.6\end{array}$

$\begin{array}{rrrr}\cdots & \ldots & 20.0 & 21.2 \\ & \cdots & 2.5 & 5.9\end{array}$

Sources: Della Paolera and Taylor (2003); International Financial Statistics (2004); and authors' calculations.

2/ Sources: Ministry of Economy and Production. Average M3 growth for 1999-02 are through 2001 only.

3/ Source: Data Resources International. Average EMBI+ figures for 1991-94 includes data from 1993-94 only. Sovereign bond spread for 1995-98 includes data from 1997-98 only.

4/ Source: Central Bank of Argentina. Figures for 1991-94 are from 1994 only.

5/ Source: Dubas, Lee and Nelson (2004). An increase indicates a peso appreciation.

6/ Source: Ministry of Economy and Production. Index is in US dollars. Year end figures.

7/ Source: Ministry of Economy and Production. 1997-2002 data are provisional.

8/ Source: Global Development Finance. Average for 1999-02 includes data through 2001 only.

9/ Sources: Secretariat of Treasury and Ministry of Economy and Production.

10/ Source: Central Bank of Argentina. Year end figures.

11/ Source: IMF international Financial Statistics 
Figure 1: Real GDP and Inflation 1980-2003

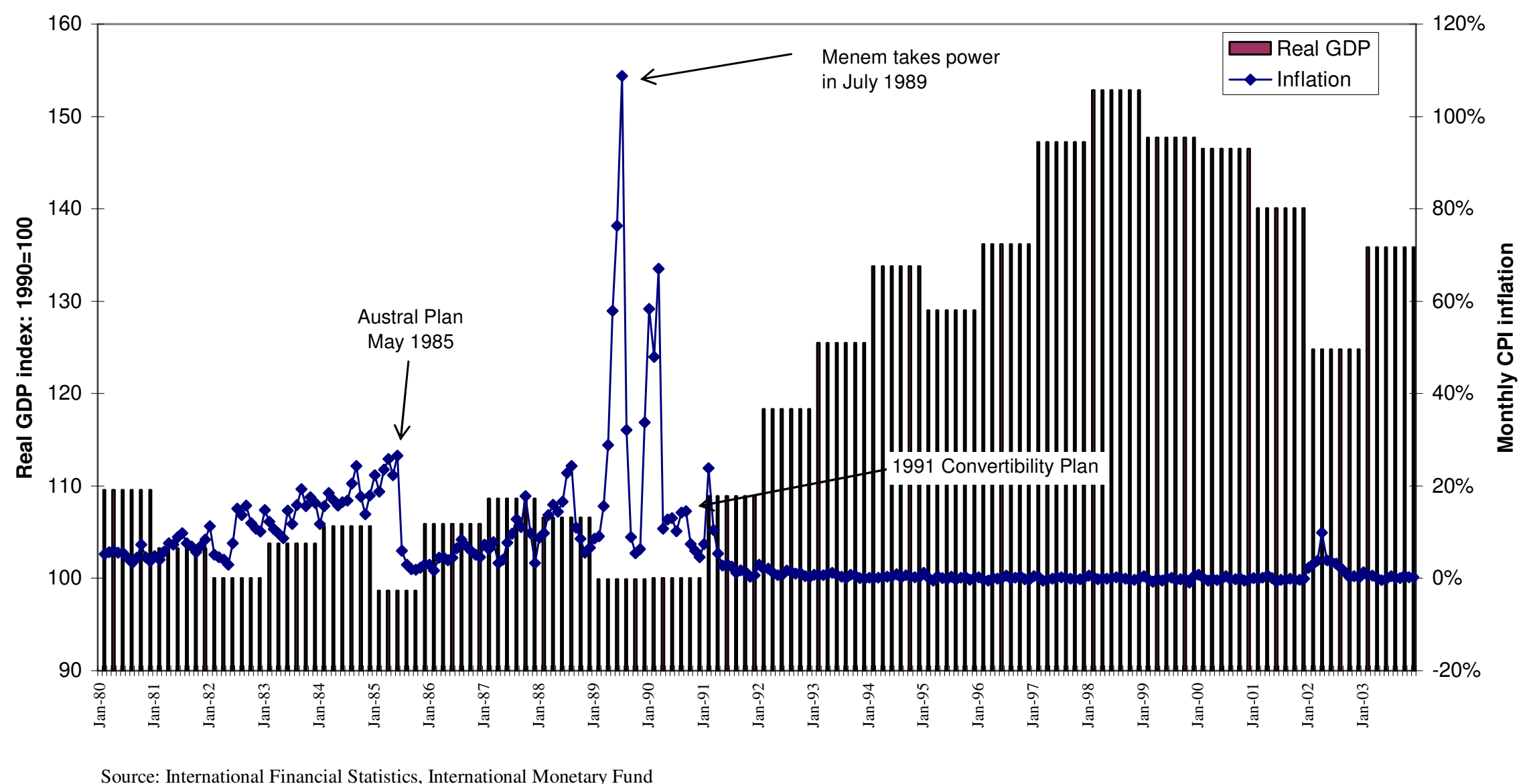


Figure 2: Mergers and Acquisitions in Argentina, 1990-2003

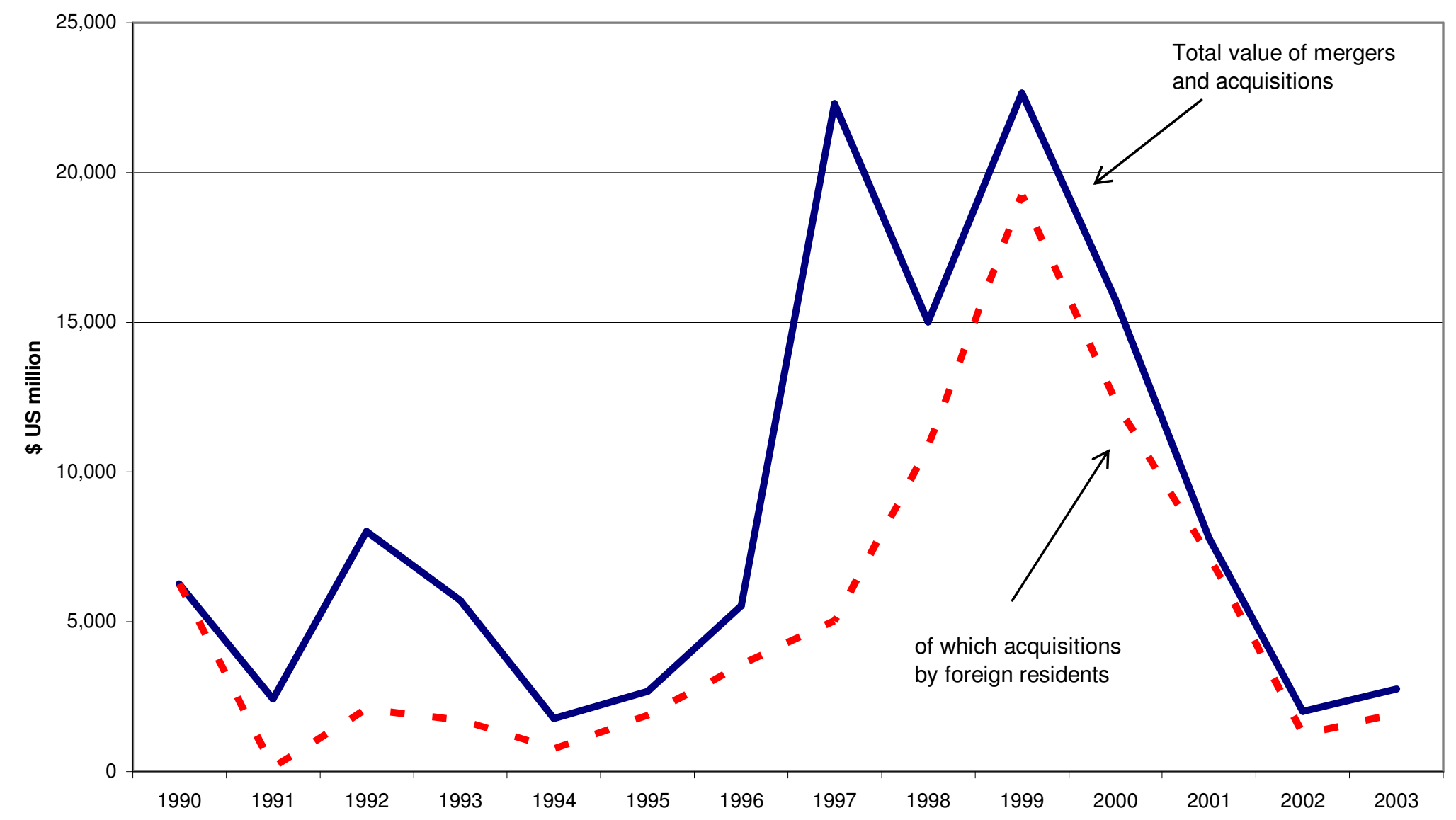

Source: Securities Data Corporation (SDC) Thompson's International Mergers and Acquisitions database 


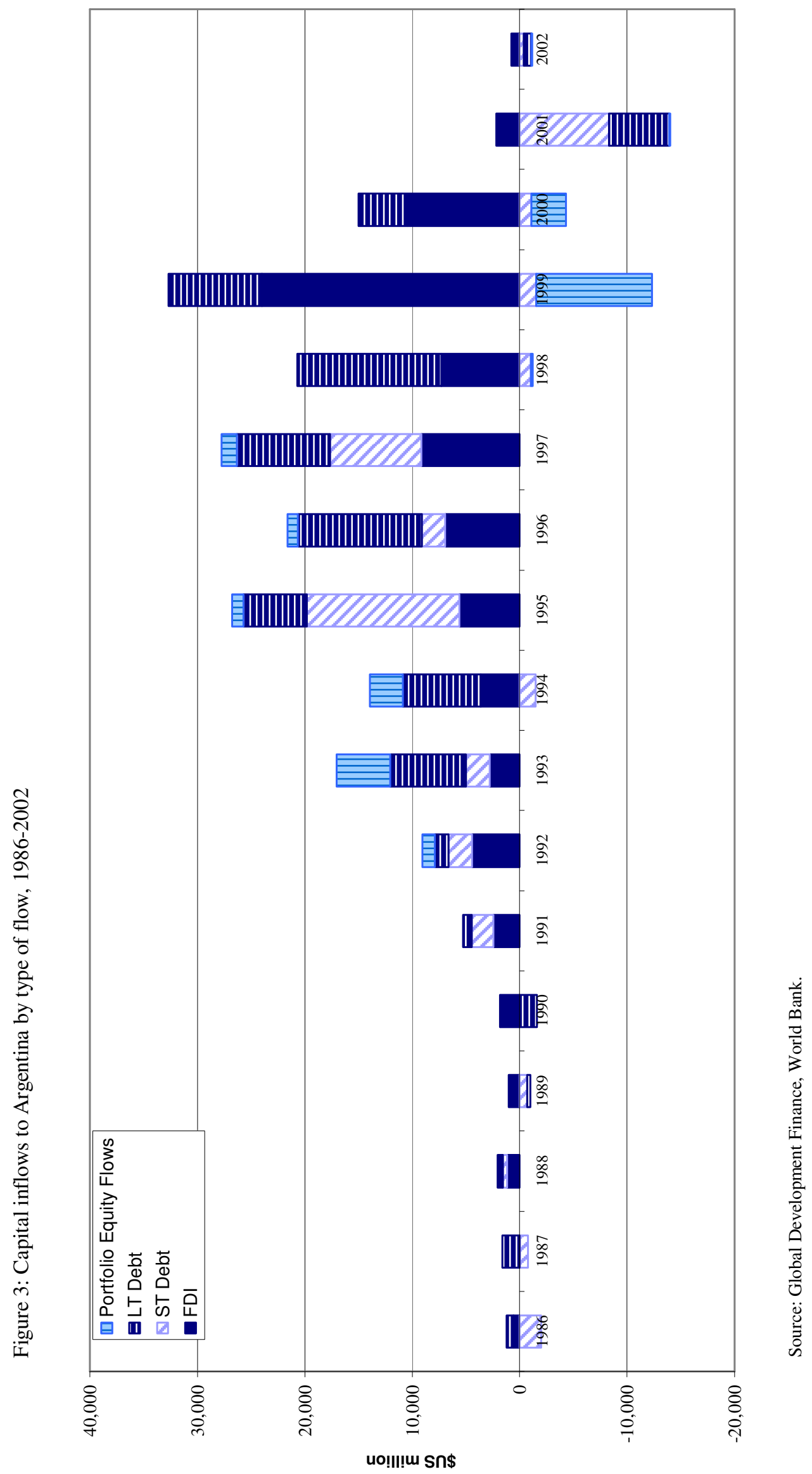




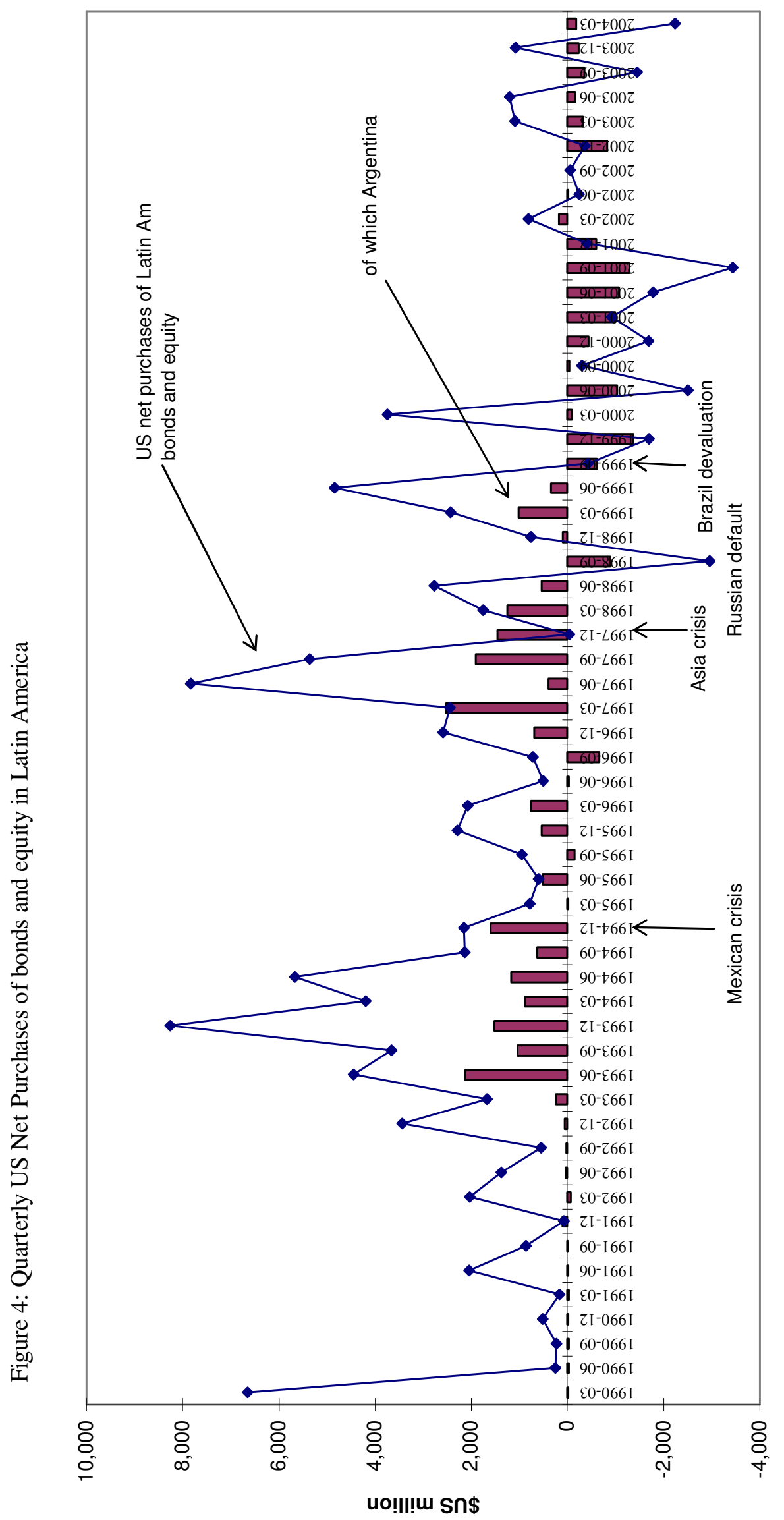




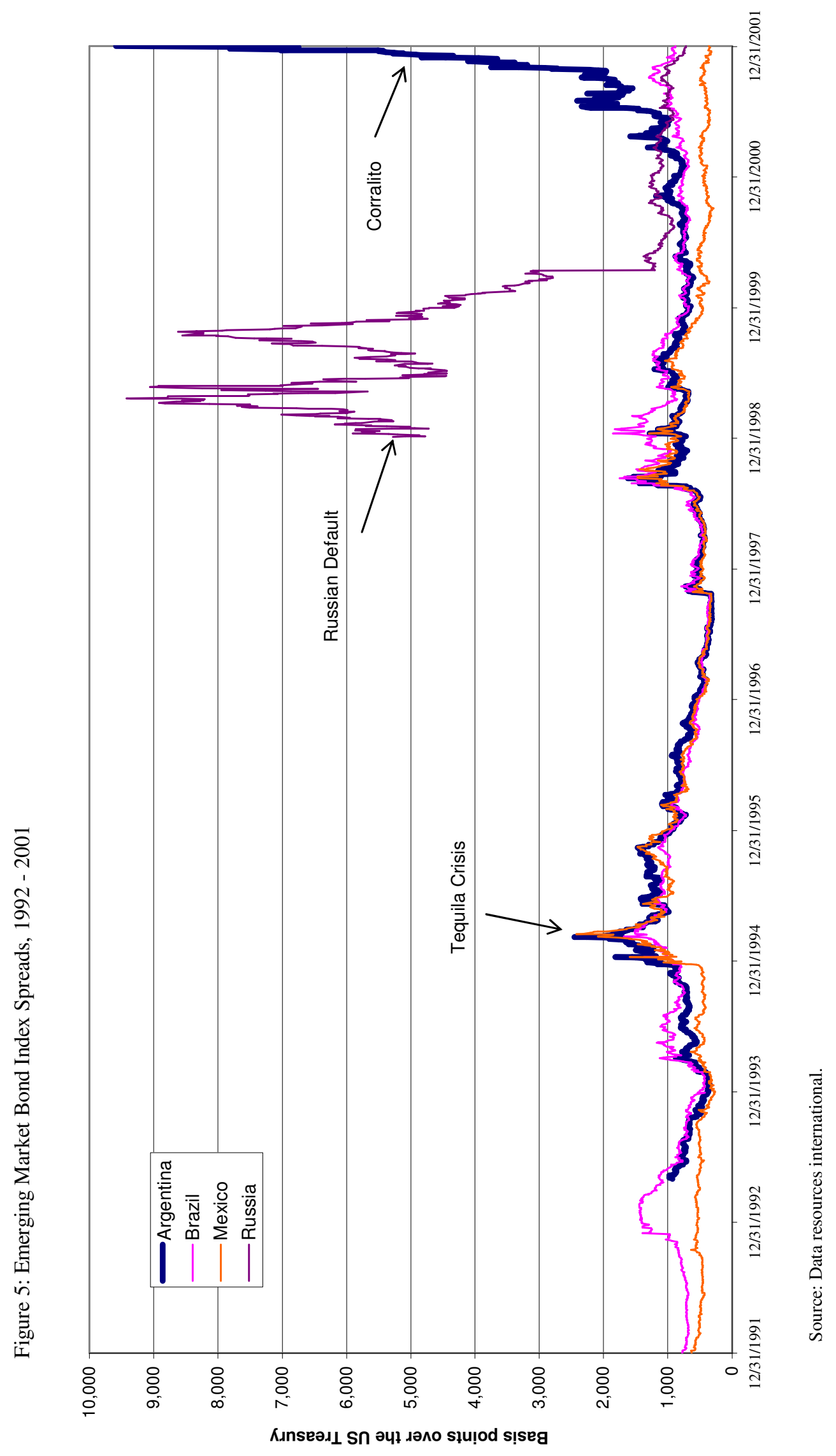




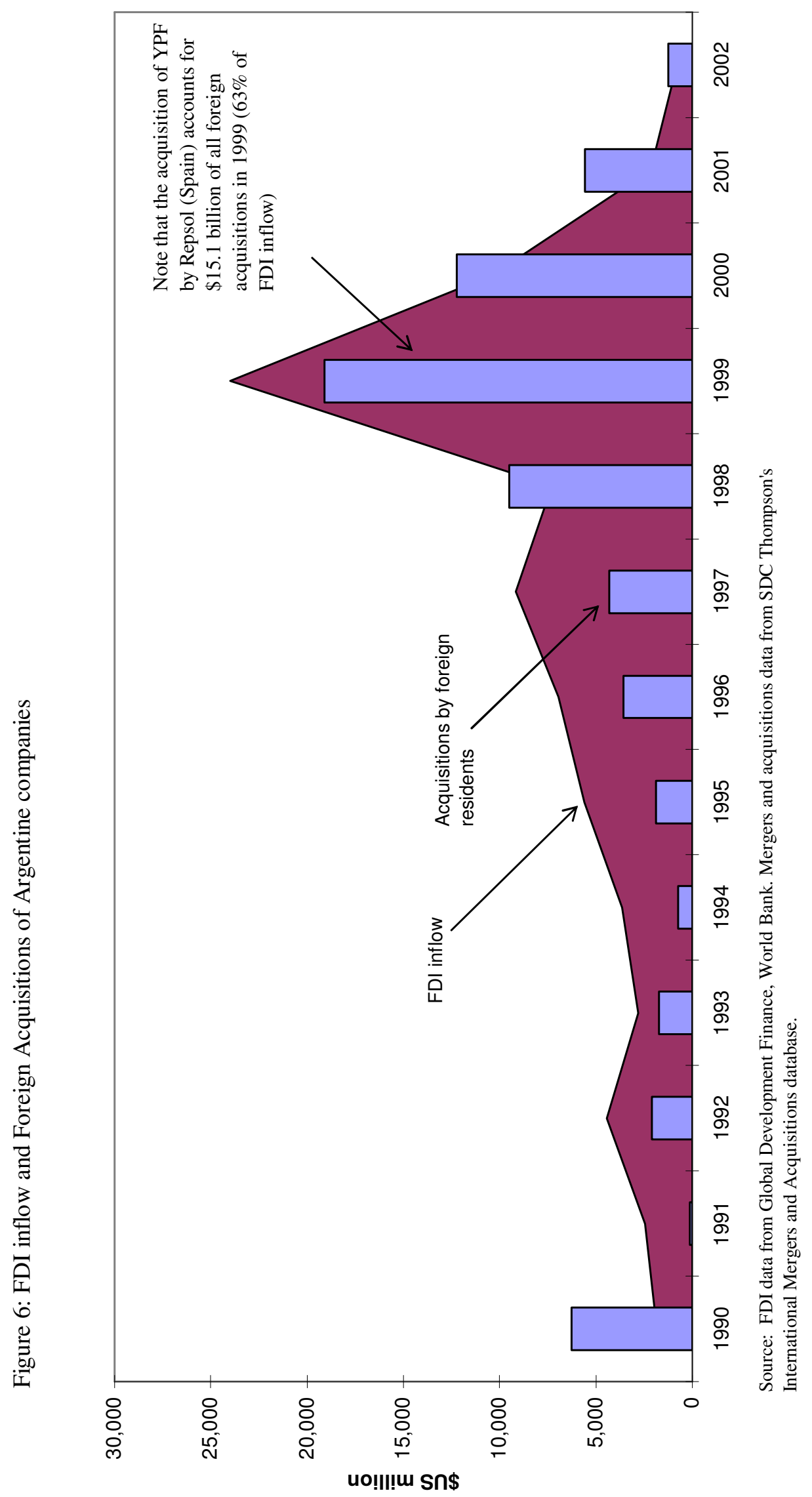




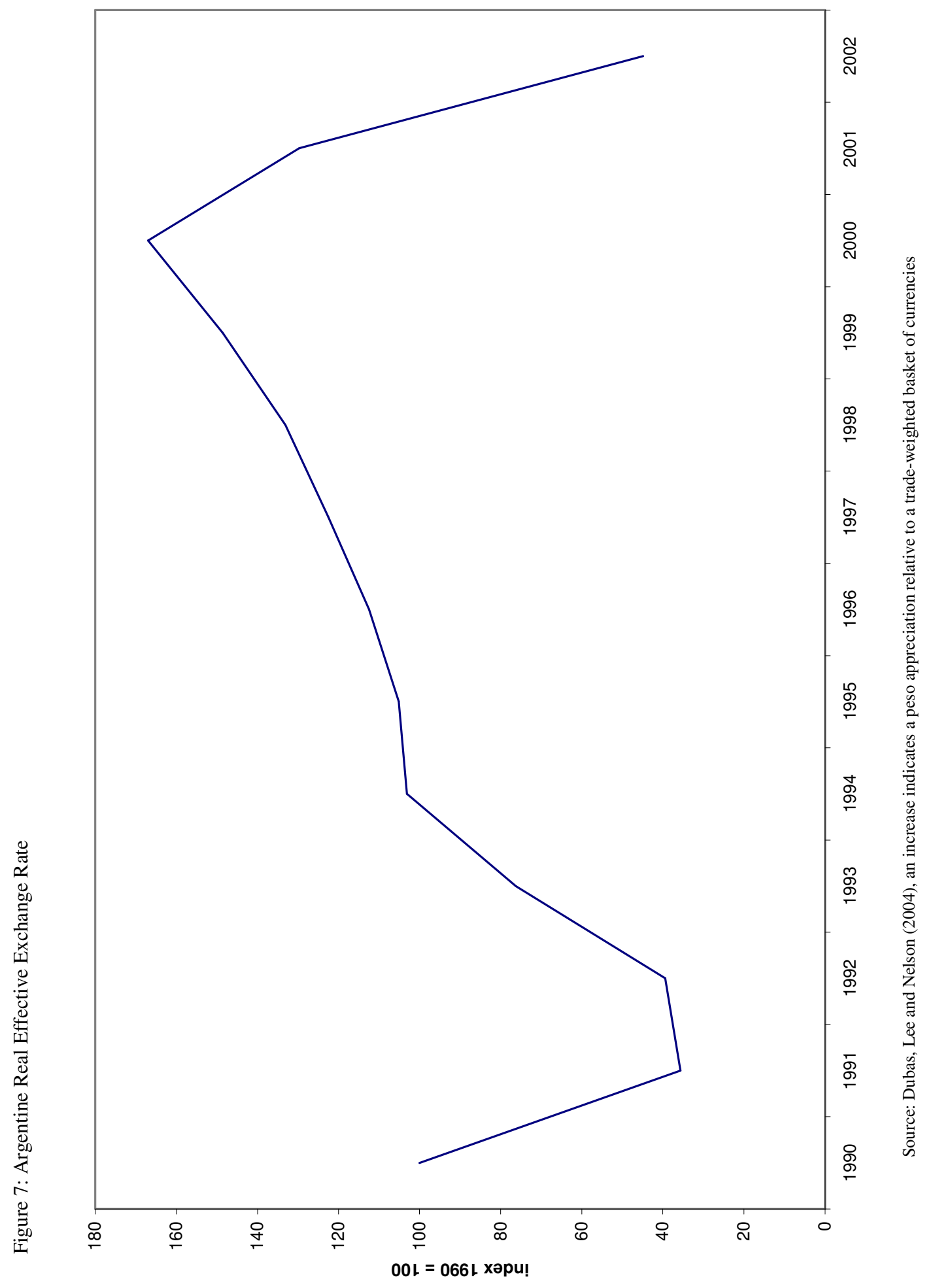




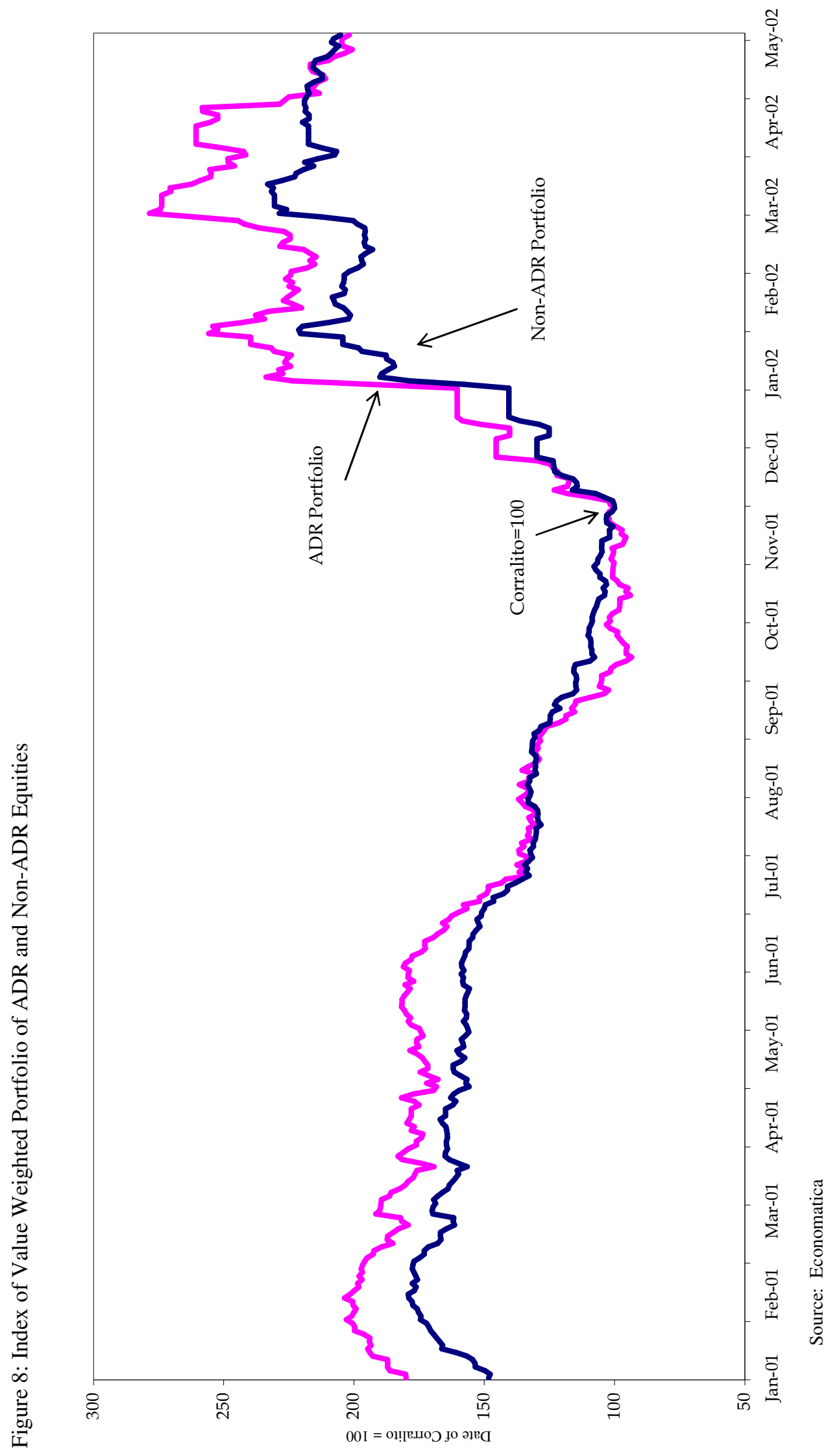




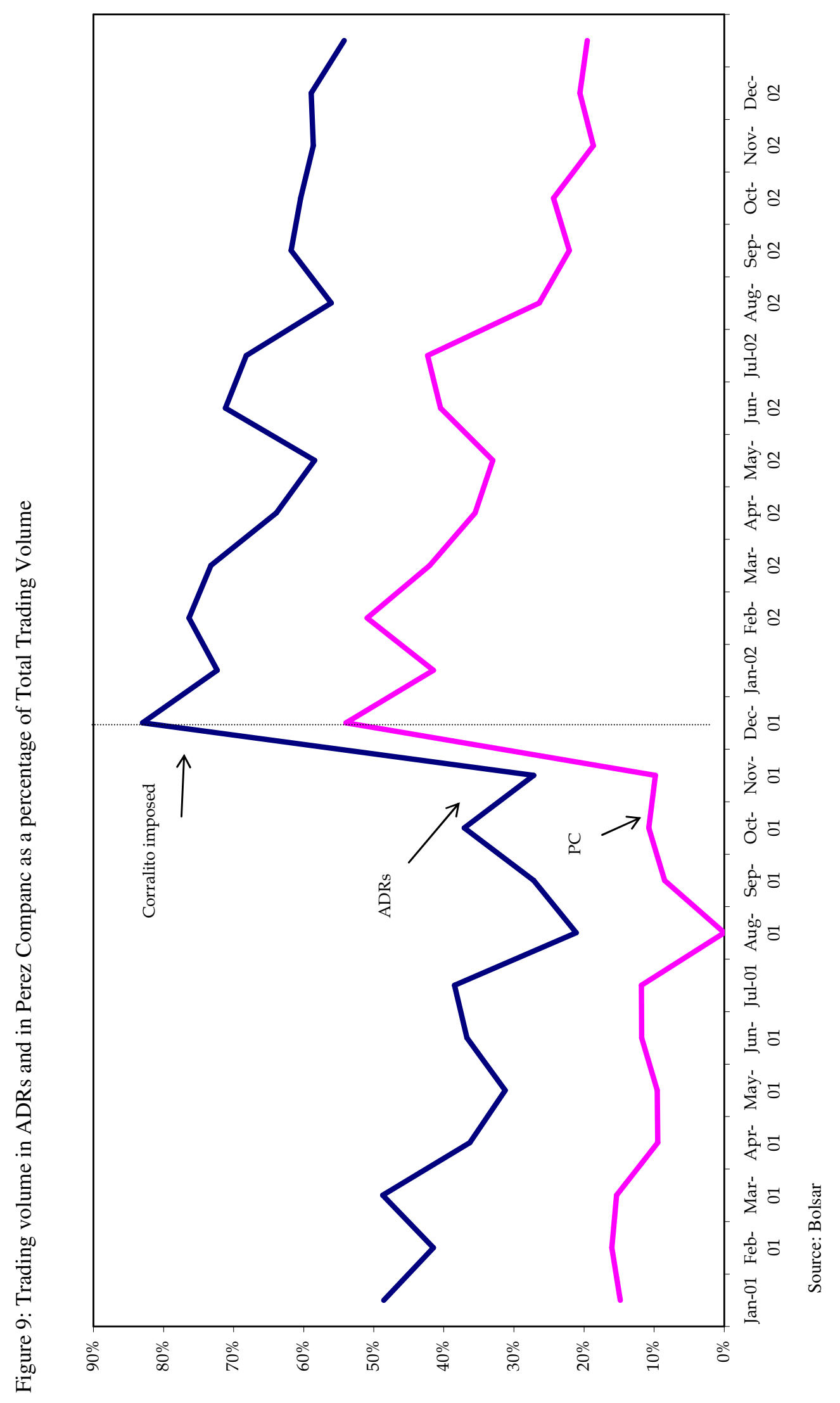

